\author{
Prof. dr. sc. Arsen Bačić \\ Pravni fakultet Sveučilišta u Splitu \\ Član suradnik Hrvatske akademije znanosti i umjetnosti
}

\title{
KONSTITUCIONALIZACIJA PATRIOTIZMA
}

\author{
UDK: $342: 4: / 72.1$ \\ Izvorni znanstveni rad \\ Primljeno: 1. 03. 2016.
}

\begin{abstract}
U tekstu se prati duga evolucija tradicionalnih ideja o patriotizmu i ustavu sve do pojave modernih ideja o ustavnom patriotizmu. Prikaz ideja o patriotizmu i njegovih oblika omogućuje zapravo uvid $\mathrm{u}$ proces konstitucionalizacije patriotizma te osvjetljava proces racionalizacije i diferencijacije patriotizma koji postoji unutar evolutivne kulture konstitucionalizma. Kroz pitanja o ustavnim sentimentima i njihovoj konstitucionalizaciji, o slabljenju i jačanju uloge patriotizma kao svojevrsnog attachmenta nacionalnog ustava, o procesu stvaranja razlika između patriotizma klasične državenacije i ustavnog patriotizma suvremenog postanja i posljedicama promjene paradigme političkog procesa u uvjetima nastanka postnacionalnog prava i njegove potrage za strukturom - tekst propituje značaj i mjesto pojave patriotizma u uvjetima nacionalne i postnacionalne ustavne države.
\end{abstract}

\section{Ključne riječi: patriotizam, ustavni patriotizam, vjera u ustav, privrženosti ustavu}

Il est certain que les plus grands prodiges de vertu ont été produits par l'amour de la patrie: ce sentiment doux et vif qui joint la force de l'amour-propre à toute la beauté de la vertu, lui donne une énergie qui sans la défigurer, en fait la plus héroïque de toutes les passions.

J. J. Rousseau, $(1755)^{1}$

1. Uvodna napomena; 2. Tradicionalna određenja patriotizma i njegovi oblici; 3. Ustavni sentimenti i konstitucionalizacija patriotizma; 3.1. András Sajó o konstitucionalizaciji ustavnog sentimenta u ustavima „herojskog doba“; 4. Konstitucionalizacija patriotizma u suvremenoj ustavnodemokratskoj državi; 4.1. Ustav SAD-a (1787.) i značenje privrženosti ustavu (constitutional attachment); 5. Postnacionalni konstitucionalizam i smisao ustavnog patriotizma novog tipa; 5.1. Europski ustav i pitanje ustavnog patriotizma; 5.2. O mjestu i ulozi europskog ustavnog patriotizma; 5.3. Odnos ustavnog patriotizma i nacionalizma; 6. Primijenjeni ustavni patriotizam: primjeri EU, Kanade; 7. Ustav Republike Hrvatske između ustavnog nacionalizma i ustavnog patriotizma; 7.1. Možemo li svjedočiti o hrvatskom ustavnom patriotizmu? 8. Zaključna napomena

1 Usp. Jean Jacques Rousseau, Discours sur l'économie politique (1755) http://classiques.uqac.ca/ classiques/Rousseau_jj/discours_economie_politique/discours_eco_pol.html 


\section{UVODNA NAPOMENA}

Krajem 1796. godine George Washington, prvi predsjednik federalnih Sjedinjenih Američkih Država odlučio je objaviti svoje povlačenje iz burnog političkog života mlade Republike. Neposredno nakon te najave, G. Washington je uz pomoć svojih bliskih suradnika Alexandera Hamiltona i Jamesa Madisona sastavio svoju „Oproštajnu adresu“ (Farewell Address) koja je imala zadaću inspirirati i voditi buduće generacije Amerikanaca, ali i braniti legat njegove administracije kojega su forte u oba mandata predstavljali konsolidacija saveznog Ustava i skupine načela federalističke doktrine. Washington je duboko vjerovao da sigurnost federalne Republike i stabilnost ustavnog dokumenta iz 1787. godine ugrožavaju geografske, političke i interesne podjele, te upletanje stranih sila u unutrašnje poslove nove nacije. U tom smislu tražio je od Amerikanaca da frakcijske ljubomore podrede nacionalnim interesima. Adresa je prvi put objavljena 19. rujna 1796. god. u Daily American Advertiseru, a kasnije u nizu drugih novina širom SAD-a. Kada je sredinom 19. stoljeća ustavno uređenje SAD-a počeo ugrožavati građanski rat, početkom 1862. god., tisuće su građana u Philadelphiji tražile od Kongresa SAD-a da u jednom od svojih domova dolazeću 130. godišnjicu rođenja G. Washingtona komemoriraju javnim i glasnim čitanjem njegova oproštajnog govora. Javno je čitanje trebalo podsjetiti narod i njegove predstavnike da političku osnovu američkog sistema vlasti predstavlja...

... pravo naroda da stvara i mijenja svoj ustav. Ali Ustav koji uvijek postoji u datom trenutku sveta je obaveza za svakoga sve dotle dok se ne promijeni eksplicitnim i autentičnim aktom cijelog naroda. Sama ideja vlasti i prava naroda da je uspostavi pretpostavlja dužnost svakog pojedinca da se pokloni uspostavljenoj vladi. ${ }^{2}$

Washingtonov poziv Amerikancima da usprkos mnogim razlikama ostanu jedinstveni povezao je „veličanje ispravnog ponosa Patriotizma“ s uvjerenjem da ostvarivanje „,slobodnog Ustava... kao djela mnogih ruku i svake grane vlasti može biti obilježeno mudrošću i vrlinom“. ${ }^{3}$ U tom smislu, Washington ustvari eksplicira ništa drugo nego jedno od najdubljih uvjerenja whigovskog konstitucionalizma 18. stoljeća. ${ }^{4}$ I to ono prema kojemu, ne samo „ekonomski rast, vladavina prava, vlasnička prava i Unija“, nego i „patriotizam“ u svojoj pionirskoj formulaciji

2 Usp. Washington's Farewell Address 1796, http://avalon.law.yale.edu/18th_century/washing.asp;

S. Bomboy, Five lessons we can learn from George Washington's Farewell Address, http://blog. constitutioncenter.org/2015/09/five-lessons-we-can-learn-from-george-washingtons-farewell-address

4 The Founding FathErs- American Whigs (1768-1783) http://www.monticellocollege.org/sites/ default/files/files/AmericanWhigs.pdf; B. Schwartz, George Washington and the Whig Conception of Heroic Leadership, American Sociological Review, Vol. 48, No. 1 (Feb. 1983), pp. 18-33. 
„liberalno nacionalne“ pozicije, kao refleks države-nacije u nastanku ima neprocjenjivu unutrašnju vrijednost u epohalnom procesu ostvarivanja liberalne demokracije.

Washingtonova adresa je zanimljiva jer ukazuje na pionirski pokušaj spajanja teme patriotizma kao ustavnog sentimenta sa značajem i ulogom državnog ustava moderne ustavnodemokratske države. ${ }^{5} \mathrm{U}$ ovome tekstu zanima nas sljedeće. Da li nam dugi vremenski raspon od tradicionalnih ideja o patriotizmu i ustavu (Periklo, Washington, Tuđman... ${ }^{6}$ do pojave modernih ideja o ustavnom patriotizmu (J. Habermas) omogućuje uvid u proces konstitucionalizacije patriotizma i na koji se način u njemu objašnjavaju razlozi racionalizacije diferencijacija koje se pojavljuju unutar evolutivne kulture konstitucionalizma? Što su to ustavni sentimenti i što nam pokazuje njihova konstitucionalizacija? Da li u tom procesu slabi ili jača uloga patriotizma kao svojevrsnog attachmenta nacionalnog ustava? ${ }^{7} \mathrm{U}$ kojoj je mjeri taj proces stvaranja razlika između patriotizma klasične države-nacije i ustavnog patriotizma suvremenog postanja zapravo posljedica promjene paradigme političkog procesa stvaranja postnacionalnog prava i njegove potrage za strukturom? ${ }^{8}$

\section{TRADICIONALNA ODREĐENJA PATRIOTIZMA I NJEGOVI OBLICI}

U Rječniku političke misli Rogera Scrutona temeljno određenje odrednice „patriotism“ upućuje na ,ljubav prema domovini“. Riječ je o širokom i neodređenom pojmu koji se koristi za različite svrhe. Za brojne pristalice tradicionalnog poimanja patriotizma riječ je o „osjećaju koji nadilazi obligaciju prema suverenu koja i njega

5 O značaju emocija za razvoj konstitucionalizma i njihovom mjestu u pravu v. A. Sajó, CONSTITUTIONAL SENTIMENTS, Yale Univ. Press, 2011; „Emotions participate in building a constitution and a culture of constitutionalism, and then these creatures of constitutional sentiment patrol emotion display. The scientific evidence indicates that reason and emotion operate interactively in human decision making as well as in the actual process of legal institution building." A. Sajó, Emotions in constitutional design, $I \bullet$ Con (2010.), Vol. 8 No. 3, 354-384.

6 U konstitucionalizmu klasičnog doba Periklov je govor Atenjanima naravno prvijenac u izgradnji političke kulture konstitucionalizma i političke pripadnosti. Usp. Demokratija i idiotizam, Vreme, 2. Januar 2003., br. 262, „Tukididove Istorije Peloponeskog rata Stjepana Telara (s početka XX stoleća, fototipsko izdanje objavio je Dereta, Beograd 1991) i Dubravke Obradović (Prosveta, Beograd 2000)“; Usp. Washington's Farewell Address 1796, http://avalon.law.yale.edu/18th_century/washing.asp; F. Tuđman, POLITIČKA I METODOLOGIJSKA POLAZIŠTA TE POLITIČKO-PRAVNA NAČELA ZA IZRADU USTAVA REPUBLIKE HRVATSKE, Izvješća Hrvatskog sabora, 3/ 9. VIII. 1990.) cit. pr. A. Milardović, DOKUMENTI O DRŽAVNOSTI REPUBLIKE HRVATSKE, Alinea, Zagreb 1992., str. 2228.

N. Walker (ed.), SOVEREIGNTY IN TRANSITION, Oxford, 2003, p. 556; P. Dobner \& M. Loughlin (eds.), THE TWILIGHT OF CONSTITUTIONALISM, Oxford University Press, 2010, p. 368.

8 Usp. N. Krisch, BEYOND CONSTITUTIONALISM-THE PLURALIST STRUCTURE OF POSTNATIONAL LAW, Oxford University Press, 2010., p. 4- 24. 
samog obvezuje“. H. St. J. Boolingbroke je u The Patriot Kingu (1738.-49.) dokazivao da je i suverenov naslov uvjetovan patriotskim djelima, iz čega proizlazi da je pravi objekt svekolike vjernosti isti kako za suverena tako i za podanike. ${ }^{9}$ Riječ je o dugovječnim idejama pa u normalnom govoru...

,... patriot cijeni ne samo državne institucije nego još više narod kojim te institucije upravljaju, te jezik, povijest i kulturu koji mu pripadaju. U tom smislu patriotizam uključuje sentiment teritorija, pa nastoji sebe hraniti vizijama prostora koje... su zasićene nostalgijom prema mjestu i klimi.“"10

Patriotizam se kao moderni koncept artikulira u procesu prije i nakon građanskih revolucija te se najčešće povezuje s evolutivnim idejama nacije, nacionalizma i etniciteta od kojih je pojmova manje heurističan. Značajno je podsjetiti da se „patriotizam“ u engleskom rječniku, kao zemlje predvodnice modernosti, ne pojavljuje prije polovice XVIII. st. To je vrijeme kada se patriotizam počinje definirati kao publick spirit u smislu ,javne duhovnosti“ (public spiritedness). ${ }^{11} \mathrm{KaO}$ pojam patriotizam prvi se put pojavio 1720., ali je zapravo, kao kombinacija ideja i retorike s kojima je bio povezan, imao korijene koliko u novoj političkoj zbilji koja se stvarala nakon Glorious Revolution (1688.-89.) toliko i u novom vokabularu građanske vrline i javne dužnosti koja je oblikovala taj prijelomni ustavni događaj u engleskoj političkoj povijesti. S početka XVIII. st. patriot želi da ga se razumije kao onoga koji...

... transcendira religijske, dinastičke i ustavne podjele iza Revolution Settlementa koje razdoblje karakterizira neriješeno stanje oko dinastičkih prava, religijske tolerancije i kvalifikacija za participaciju u javnim službama, i nastojanje da se osiguraju slobode otkrivene u revoluciji promocijom građanske vrline i ustavnih prava posjedničke elite u zemlji. ${ }^{12}$

Engleski je leksikograf S. Johnson u svojem pamfletu The Patriot (1774.) definirao patriota kao ,čovjeka kojemu je najveća strast ljubav prema domovini““. ${ }^{13}$ U četvrtom izdanju svog glasovitog rječnika Johnson je dodao da se ta riječ ponekad

9 H. St. J. Bolingbroke, The Idea of a Patriot King, http://socserv2.socsci.mcmaster.ca/ econ/ugcm /3113/ bolingbroke/king.html; Bolingbrokeova knjiga iz 1749. adaptirala je jezik patriotizma zbog kritike političkih teorija kojima je tadašnji premijer Walpole opravdavao svoju politiku.

10 R. Scruton, PATRIOTISM, u: A DICTIONARY OF POLITICAL THOUGHT, Pan Books, London 1982., p. 347-348; Usp. Patriotizam, odrednica u: BLACKWELLOVA ENCIKLOPEDIJA POLITIČKE MISLI M-Z, Zagreb, 2003., str. 463.

11 J. Foreman, The Pocket Book of Patriotism, Sterling Publishing Company, Inc., 2005., 96.

12 J. Crowe, Patriotism and Public Spirit-Edmund Burke and the Role of the Critic in Mid-EighteenthCentury Britain, Stanford University Press, 2012., Introduction, p. 3.

13 S. Johnson, THE PATRIOT - ADDRESSED TO THE ELECTORS OF GREAT BRITAIN, 1774. From „The Works of Samuel Johnson“, published by Pafraets \& Company, Troy, New York, 1913; volume 14, pages 81-93., http:/www.samueljohnson.com/thepatriot.html 
koristi kako bi se na poseban način obilježili „opozicijski elementi“. ${ }^{14}$ Upravo u tom kontekstu treba razumjeti njegovu najpoznatiju referencu o patriotizmu kao o „,zadnjem utočištu nitkova“. Ta se je opaka opaska zapravo odnosila na pristalice Patriot Party koja je u Johnsonovo vrijeme djelovala u parlamentarnim frakcijskim borbama, a posebno na „lažni patriotizam“ „whigovaca“ (Patriot Whig) okupljenih oko Williama Pitta starijeg. ${ }^{15}$

U herojskom razdoblju uspostave modernog parlamentarizma najprije u Engleskoj a zatim i drugdje u Europi kada države još uvijek predstavljaju ustavni monarsi, okrunjene glave, od njihovih se podanika očekivala lojalnost i pokornost, spremnost da dadu ,„̌ivot za svog kralja“, ali svakako ne i ,javna produhovljenost“. Ako etimološko značenje patriotizam (patriotizam-patria-domovina, otadžbina $)^{16}$ u povijesnom smislu povezuje s ,kraljem“ (patrimonijalna teorija), ${ }^{17} \mathrm{u}$ njemu se isto tako reflektiraju i trenuci prijelaza između domovine i nacije; patriotizam u početku još uvijek ispunjava vjernost sina prema kralju, da bi kasnije građani umirali za apstraktniju socijalnu tvorevinu koja ipak ne zatire raniji sentiment. O ratovima su odlučivali carevi, kraljevi i prinčevi, a ne njihovi narodi. Očekivalo se da takvom javnom svijesti budu prožeti samo građani a ne i podanici. ${ }^{18}$ Otuda veza patriotizma s uspinjućom teorijom narodnog suvereniteta. A taj je razvitak ipak ovisio o otkriću ili objavi revolucionarnih principa o pravima čovjeka i ustavotvornog kapaciteta naroda (We the People). ${ }^{19}$

Iz principa Hobbesovog Leviathana (1651.) i Lockeovih Two Treatises of Government (1690.) pojavljuje se nova organizacija državne vlasti, a s njome se pojavljuje inovo razumijevanje patriotizma, koje je predstavljalonešto više odljubavi prema domovini. Alexis de Tocqueville je bio prvi suvremeni konstitucionalist koji prepoznaje tu novu formu patriotizma. U djelu De la démocratie en Amérique (1835.) Tocqueville dokazuje da je patriotizam racionalniji od puke ljubavi prema domovini. Patriotizam je rođen u prosvjetiteljstvu, a „raste s širenjem prava“. Nešto kasnije od Tocquevillea, A. Lincoln je govorio o founding fathersima iz

14 A Dictionary of the English Language, A Digital Edition of the 1755 Classic by Samuel Johnson, http://johnsonsdictionaryonline.com/

15 C. Gerrard, The Patriot Opposition to Walpole: Politics, Poetry, and National Myth, 1725-1742 (London: Oxford University Press, 1995); C. Condren, Argument and Authority in Early Modern England: The Presupposition of Oaths and Offices, Cambridge University Press, 2006., p. 399.

16 Usp. B. Klaić, RJEČNIK STRANIH RIJEČI, odrednica PATRIA, Zagreb, 1987., str. 1019.

17 I. Ermakoff, Patrimonial rise and decline. The strange case of the familial state, Esmerald, 2008.; J. Adams, The Rule of t he Father: Patriarchy and Patrimonialism in Early Modern Europe, https://www. russellsage.org/sites/all/files/u4/ Adams_Rule\%20of \%20the \% 20 Father.pdf

18 „Patriotism was a way of enchancing the social role of rising German educated bourgeoise." Usp. S. Weichlein, COSMOPOLITANISM, PATROPTISM, NATIONALISM, u: Unity and Diversity in European Culture c.1800, Proceedings of the British Academy, 134, p. 77, 99., http://doc.rero.ch/record/ 200211/files/Weichlein_Cosmopolitanism_patriotism_nationalism_m.pdf

19 B. Ackerman, We the People, Volume 1: Foundations, Harvard University Press, 1993, p. 384. 
1776. godine kao o ,patriotima“, ali ne zato što su „ubijali britansku braću“, već zbog uspostave SAD-a kao nove slobodne države koja je ,zemaljska nada“. Bilo je patriota - Lincoln je posebno veličao Henryja Claya (1777. - 1852.) - koji su svoju zemlju voljeli ne samo zato što je riječ o njihovoj zemlji već zato jer ona bila slobodna; ,najznačajniji među njima nisu radili samo za njen napredak, prosperitet i slavu, već su to radili i za napredak, prosperitet i slavu ljudske slobode, ljudskih prava i ljudske prirode“. ${ }^{20}$ Drugim riječima, H. Clay bio je patriot jer se borio za ideju o svojoj zemlji i za njezine principe. Da u tim principima nije bilo ništa „parohijalno“, među prvima je shvatio još Edmund Burke imajući u vidu svekoliki revolucionarni i eksportni kapacitet alarmantnih novina narodnog ustanka u Francuskoj. Burke je bio čvrsto uvjeren u potrebu „,nacionalizacije“ tih novina jer, ukoliko one ne prođu kroz nacionalno „sito i rešeto“, reducirat će ne samo francuski već i svaki drugi narod u Europi u jednu ,homogenu masu“. Otuda teza da je pokušaj eksporta Revolucije i njezinih univerzalnih principa potakao na glorifikaciju nacije, nacionalizma i politike etniciteta, u kojem se je procesu patriotizam spojio ne s političkim principima već s pitanjima ,krvi i tla““. ${ }^{21}$

Danas se pojam patriotizma sagledava na više načina. U najvećem broju slučajeva taj se pojam koristi u moralno ispunjenoj perspektivi: u njoj se patriotizam najčešće definira kao ,spremnost građana da poginu za svoju zemlju“, ,patriotizam je respektabilan jer se odnosi na defanzivno, herojsko ponašanje nacije koja je izvrgnuta napadu“. ${ }^{22}$ Patriotizam se ponekad identificira s nacionalizmom, a ponekad se od njega oštro diferencira. U preambuli Ustava SSSR-a (1977.) sovjetski su građani nazivani ,patriotima i internacionalistima“. ${ }^{23}$ Potonja je formulacija sugerirala zaključak da je patriotizam značio puno više od nacionalizma. Nacionalizam precizno opisuje one koji su angažirani u agresivnoj, ekspanzionističkoj politici. Ipak, za Michaela Ignatieffa otvoreno je pitanje: Može li se imati patriotizam bez nacionalizma?. ${ }^{24}$ I jedno i drugo mogu biti dvije strane jedne te iste medalje. Zato ta dihotomija zavodi kao i ona između civilnog, liberalnog nacionalizma s jedne

20 A. Lincoln, Eulogy on Henry Clay, July 6, 1852, Springfield, Illinois, http://www. abrahamlincolnonline. org/lincoln/ speeches/clay.htm

21 Usp. W. Berns, On George Kateb's Patriotism, Response Essays, March 12, 2008, http://www. cato-unbound.org/2008/03/12/walter-berns/george-katebs-patriotism

22 Usp. A. Appadurai, PATRIOTISM AND ITS FUTURE, Public Culture 5/1993., cit. pr. C. Jaffrelot, FOR A THEORY OF NATIONALISM, Questions de recherche/Research in question-no. 10June 2003, http:www.ceri-sceinces-po.org/publica/qdr.htm

23 CONSTITUTION (FUNDAMENTAL LAW) OF THE UNION OF SOVIET SOCIALIST REPUBLICS, Adopted at the Seventh (Special) Session of the Supreme Soviet of the USSR Ninth Convocation On October 7, 1977 http://www.departments.bucknell.edu/russian/const/77cons01. html\#preamble

24 M. Ignatieff, BENIGN NATIONALISM? POSSIBILITIES OF THE CIVIC IDEAL, u: E. Mortimer (eds.) ETHNICITY. THEORY AND EXPERIENCE, Cambridge (Mass), Harvard University Press, 1975, p. 141). 
strane i etničkog, zatvorenog nacionalizma s druge strane. Opći je zaključak da u toj dihotomiji postoji veliki stupanj podudarnosti. ${ }^{25}$

S druge pak strane, „republikanski patriotizam“ može biti itekako snažan protuotrov nacionalizmu. I njegov je jezik kao i jezik nacionalizma eminentno retoričan: on prije smjera i cilja oživljavanju, jačanju i usmjeravanju strasti određenog naroda sa specifičnim kulturnim i povijesnim identiteom nego li postizanju razložnog odobrenja impersonalnih racionalnih čimbenika. I on nastoji ojačati veze, poput naklonosti narodnoj slobodi, koja je isto tako određena poput ljubavi, ili ponosa u kulturnoj tradiciji ili zajedničkoj sudbini naroda. Upravo zbog toga što se patriotizam natječe $s$ nacionalizmom na istom terenu strasti i partikularnosti, i zato što prije koristi retoričke nego li racionalne argumente, on je ozbiljan oponent nacionalizmu. Patriotizam radi na solidarnosti i bratstvu tako da se ti osjećaji transmutiraju u snage koje prije podržavaju slobodu nego što potiču isključivanje ili agresiju. ${ }^{26}$

Navedena stajališta, kao i niz drugih, samo su dio širokog spektra različitih aspekata patriotizma. No, svi oni obogaćuju njegovo razumijevanje i to iz nekoliko perspektiva. Različiti pristupi postavljaju različita pitanja koja traže odgovore. Jedno je od ključnih pitanja i ono o tome je li patriotizam prije građanskih revolucija predstavljao ideologiju, koja je poput modernog nacionalizma, bila u stanju motivirati narod. Druga se pitanja usmjeravaju prema religiji, njezinoj osjetljivosti i djelovanju prema različitim etnofobijama, njezinom jeziku i uvjetima njezine upotrebe. Ono što je izvan svake sumnje jest činjenica mijenjanja političkog jezika što se onda reflektira i u jeziku patriotizma. O tim promjenama i posljedicama dovoljno znakovito govori svjedočanstvo Abbéa de Vérija iz 1779.

„Trivijalni izrazi moje mladosti: „Služba Kralju je služba Domovini“... ne prenose više one impresije veličine ili prezira koje su Francuzi nekada imali. Rijetko se danas tko usudi kazati: ,služim Kralju“, danas kažu „služim Državi“. Posljednji je izraz u vrijeme Louisa XIV. bio svetogrđe. Za prvih dvadeset godina vladavine Louisa XV. vidjeli smo ostatke takvog načina razmišljanja, onda kada je ministar na jednoj akademiji protestirao protiv fraze: služimo Naciji. Tamo je govorio: „U Francuskoj nema nacije, postoji samo Kralj“. Danas bi se u pariškim krugovima rijeko tko usudio kazati: Ja služim Kralju. Zaslužio bi mjesto utjecajnih sobara

25 Usp. C. Jaffrelot, FOR A THEORY OF NATIONALISM, Questions de recherche/Research in question-no. 10-June 2003, http:www.ceri-sceinces-po.org/publica/qdr.htm, p. 4.

26 T. Donahue, Viroli, Maurizio. For Love of Country: An Essay on Patriotism and Nationalism. Oxford, Clarendon Press, 1995. http:/www.nationalismproject.org/books/bookrevs/viroli.html; W. Lippmann, Patriotism and state sovereignty A Preface to Morals (1929.) http://www.panarchy.org/ lippmann/patriotism.html; I. Primoratz, „Patriotism“, The Stanford Encyclopedia of Philosophy (Spring 2015 Edition), Edward N. Zalta (ed.), URL = <http://plato.stanford.edu/archives/spr2015/ entries/ patriotism/> 
u Versaillesu. Danas se najčešće čuju izrazi: „Služim Državi“, ili „Služio sam Državi!“" Naravno da razlika između izraza označava razliku u sentimentima.“27

Upravo je postojanje ,razlika u sentimentima“ o kojima govori Abbé de Véri omogućilo kasnije jasniju diferencijaciju oblika patriotizma. Dva su dominantna oblika: jaki (strong) i umjereni patriotizam (moderate patriotism). Prvi dokazuje da je patriotska lojalnost jedini izvor bilo kakvih iole značajnih moralnih zahtjeva. Sadržaj patriotizma bi uvijek bio partikularan ili lokalan. Ovdje se lojalnost koja se traži od patriota odnosi na vrijednosti koje se u određenoj zajednici ili državi smatraju dominantnima. Ovaj je patriotizam suvremeni filozof A. MacIntyre formulirao kao klasu ,vrline kojom se iskazuje lojalnost“. Riječ je o vrlinama koje streme akcijama određenih osoba ili grupa unutar visoko partikularno izraženih odnosa. Moralnost je za ovog filozofa uvijek ukorijenjena unutar bliskih odnosa zajednice. Moralnost patriotizma nam je prirodna jer smo bića koja pripadaju određenoj zajednici. ${ }^{28}$ Ipak, u 20. st. najjače varijante patriotizma bile su povezane s militarističkim ili ratnohuškačkim pozicijama njemačkih nacista i talijanskih fašista. ${ }^{29}$

Protivljenje tom stajalištu dolazi od univerzalističkih argumenta i zahtjeva koje artikulira doktrina o općim ljudskim pravima. Najveći dio suvremenih stavova o patriotizmu pripada kategoriji umjerenog patriotizma dakle onoj koja posreduje između univerzalizma i lokalizma. Nekoliko je njegovih varijanti. Tako se: (i) neoklasični republikanski patriotizam fokusira na političku slobodu i građansku vrlinu. Ljubav prema domovini nije ljubav prema jeziku ili etnicitetu, već prema političkoj slobodi. (ii) Za komunitarni patriotizam postoji veza između patriotizma, republikanizma i komunitarnih motiva. Tako za $\boldsymbol{C}$. Taylora umjereni komunitarni patriotizam nema predpolitičke reference. Ovdje se intencionalno pristaje uz zemlju i njezine zakone. ${ }^{30}$ (iii) Liberalni patriotizam S. Nathansona jest sredina između spomenuta dva stajališta. Ova struja izbjegava svaku krajnost naglašenog

27 P. R. Campbell, The Language of Patriotism in France, 1750-1770, e-France, Volume I, 2000., https:/www.reading.ac.uk/web/FILES/e-france/Campbell - Language of Patriotism.pdf; J.Espíndola, A Criticism of Edmund Burke's Conception of Patriotism, $\bar{h}$ ttp://www.scielo.org.mx/pdf/ trf/n46/n46a5. pdf; Usp. I. Crowe, Patriotism and Public Spirit: Edmund Burke and the Role of the Critic in MidEighteenth-Century Britain, Stanford University Press, 2012., p. 320.

28 A. MacIntyre, IS PATRIOTISM A VIRTUE?, The Lindley Lecture, University of Kansas, March 26, 1984., https://mirror.explodie.org/Is\% 20 Patriotism\%20a\%20Virtue-1984.pdf; AFTER VIRTUE, http://epistemh. pbworks.com/f/4.+Macintyre.pdf

29 G. Claeys, The Lion and the Unicorn, Patriotism, and Orwell's Politics, The Review of Politics / Volume 47 / Issue 02 / April 1985, pp 186-211.

30 Usp. Patriotism - Forms Of Patriotism - Moderate, Strong, Communitarian, and Liberal - JRank Articles, http://science.jrank.org/pages/10611/Patriotism-Forms-Patriotism.html; Charles Taylor's Vision of Modernity: Reconstructions and Interpretations, Ed. C. Garbowski, J. Hudzik and J. Kłos, Cambridge Scholars Publishing 2009. 
patriotizma i liberalnog univerzalizma. Patriotizam traži srednji put. ${ }^{31}$ (iv) Najnovija su stajališta ona o ustavnom patriotizmu J. Habermasa koji se razumije kao lojalnost univerzalnim načelima slobode i demokracije konstitucionaliziranima u ustavu. Verfassungspatriotismus za Habermasa predstavlja patriotsku lojalnost univerzalnim načelima kakve npr. sadrži njemački Ustav (Grundgezetz) koji povezuje građane kao formalni zajednički sporazum o zajedničkim ustavnim vrednotama. Za Habermasa ustavni patriotizam nema nikakve veze s predpolitičkim stajalištima koja su karakteristična za nacionalizam ili ,,jaki patriotizam“. ${ }^{32}$

Dakle, ako u najvećem broju određenja patriotizma nalazimo izraze ,ljubavi za institucije, običaje i narod određene zemlje“, ili ,lojalnost kao vjernost ali ne više kao u starim vremenima, kraljevima i plemenitašima, već Ustavu i zakonima zemlje", ${ }^{33}$ na koji su se način i zašto konstitucionalizirali i legalizirali sentimenti? ${ }^{34}$

\section{USTAVNI SENTIMENTI I KONSTITUCIONALIZACIJA PATRIOTIZMA}

Definiranje patriotizma nalikuje putovanju između Scile i Haribde. Martha C. Nussbaum potragu za smislom patriotizma opisuje glavinjanjem između višeglave Scile i Haribdinog vrtloga. To putovanje označuje zapravo opasnosti i posljedice prihvaćanja njegovih brzopletih i jednostranih određenja. Višeglava Scilina kreatura označuje više prijetnji: opasnost od priklanjanja pogrešnim i isključivim vrednotama; opterećenje manjinskom svijesti koju pritišću ritualne izvedbe, te prenaglašenim isticanjem solidarnosti i homogeniteta koji prijete zamračivanjem kritičke svijesti. S druge strane, Haribda svojim vrtlozima i strujama prijeti zaustavljanjem i uništenjem svih koji se uspiju odmaknuti od Scilinih zubatih glava. No, Haribda je u okvirima ove argumentacije opasnost ,razvodnjene“ motivacije,

31 S. Nathanson, Patriotism, Morality, and Peace, Studies in Social, Political, and Legal Philosophy, Rowman \& Littlefield Publishers, 1993., p. 220.

32 J. Habermas, The Postnational Constellation: Political Essays (Studies in Contemporary German Social Thought) 1st MIT Press, 2001., 216 pages; usp. i stajališta o oblicima patriotizma na http://science. jrank.org/pages/10611/Patriotism-Forms-Patriotism.html

33 „Patriotism means love of the institutions and customs and peoples of one's country in general. Loyalty is allegiance, not, as elsewhere or in former times, to kings and nobles, but to the Constitution and laws of our country in both its State and Federal forms. Loyalty to an administration or party may be disloyalty in the true sense of the word, and must be so, if the administration or party be itself unfaithful to the Constitution and laws. Our oath and duty of allegiance are to the Constitution, and not to any administration. The President is not the government, but an administrator of it, according to the laws of the Constitution, and he, as every other officer is sworn to administer it according to that standard and in allegiance to it. They owe the same allegiance we do." "The Causes and Dangers of Social Excitement." The Knickerbocker, Vol. LXIII, No. 6 June 1864 - Page 486; http://stuffnobodycaresabout. com/ page/41/

34 G. Kateb, On Patriotism, Lead Essay, March 10, 2008; http://www.cato-unbound.org/2008/03/10/ george-kateb/patriotism 
one koja, prema Aristotelu, opsjeda svako društvo koje sebe pokušava voditi bez partikularizirane ljubavi ili zanosa. ${ }^{35}$ A primjeri političkog djelovanja Abrahama Lincolna, Martina Luthera Kinga Jr., Mohandasa Gandhija i Jawaharlal Nehrua uvjerljiva su ilustracija ličnosti koje su uspjele afirmirati oblik patriotizma koji je kao ustavna vjera (constituional faith), oslanjajući se na ustavni dokument, sve prebrodio i opstao unatoč svim iskušenjima povijesno-temporalnog tjesnaca. ${ }^{36}$ $\mathrm{U}$ tom pravcu se evolucija konstitucionalizma u okvirima ustavnodemokratske države 19. i 20. st. može promatrati i kao proces slaganja kompliciranog okvira normativnih i političko-pravnih obligacija patriotizma. ${ }^{37}$

3.1. András Sajó o konstitucionalizaciji ustavnog sentimenta u ustavima „herojskog doba“. Kao djelo prosvjetiteljstva 18. stoljeća, moderni je konstitucionalizam prije svega obilježavala nepopustljiva vjera u ljudski razum. Nova je vjera u ratio prije svega označavala spremnost da ljudski razum, slobodan od svih predrasuda prošlosti i iracionalnosti, bude mjerilo svih stvari. No, ljudski je razum jedno, a vjera u njega nešto sasvim drugo. I. Kant u svom Manifestu o prosvjetiteljstvu (1784.) ističe da iza hladne i apsolutne logike (racionalnog) argumenta leži emocija: kvazireligiozni entuzijazam kojim filozof pretače sile ljudskog mišljenja kako bi oslobodio um od svih prošlih prepreka. Nakon uklanjanja suvišnih proteza, razum će slobodno zakoračiti i u maršu naprijed osloboditi čovječanstvo njegovih ograničenja. ${ }^{38}$ Sve prosvjetiteljske zahtjeve i racionalne ciljeve trebao je reflektirati pisani ustav kao juridička kodifikacija temeljnih pravila na kojima počiva državni i društveni poredak. S juridičkog stajališta, ustav je kao temeljni zakon doslovno konstituirao legalne uvjete mogućnosti države.

Ipak, sve je više suvremenih konstitucionalista koji propituju opću pretpostavku konstitucionalizmu koji počiva na racionalizmu i relaciju razum-emocija u samim temeljima dominirajuće paradigme „vladajućeg regulatornog modela“. Tako András Sajó smatra da su u oblikovanju ustava svoj obol dali i sentimenti koji

35 F. Mangena, Aristotle, patriotism and reason: Reflections of MacIntyre's question - is patriotism a virtue? http://www.phronimon.co.za/index.php/phroni/article/view/11

36 Martha C. Nussbaum, TEACHING PATRIOTISM: LOVE AND CRITICAL FREEDOM, July 2011. This paper can be downloaded without charge at the Public Law and Legal Theory Working Paper Series: http://www.law. uchicago.edu/academics/publiclaw/index.html and The Social Science Research Network Electronic Paper Collection.

37 S. Levinson, CONSTITUTIONAL FAITH, Princeton University Press, New Jersey 1988, p. 250; M. Gilbert, A THEORY OF POLITICAL OBLIGATION, Clarendon, Oxford University Press, Oxford 2006, p. 332; András Sajó, CONSTITUTIONAL SENTIMENTS, Yale University Press. New Haven and London, 2010, 400 pp. pp. 446-452.

38 I. Kant, An Answer to the Question: What is Enlightenment? 1784, https://www. marxists. org/ reference/subject/ethics/kant/enlightenment.htm, McDowell, G., O'Neill, J. (Eds.) America and Enlightenment Constitutionalism, Palgrave Macmillan, 2006, VII-270. J. Waldron, Isaiah Berlin's Neglect of Enlightenment Constitutionalism (April 2014). NYU School of Law, Public Law Research Paper No. 14-12. Available at SSRN: http://ssrn.com/ abstract=2410388 or http://dx.doi.org/10.2139/ ssrn. 2410388 
su imali značajnu ulogu u regulatornoj karakterizaciji temeljnih ljudskih emocija kolektiva. Otuda njegov zaključak o ozbiljnom razmatranju i kvalificiranju svakog onog nastojanja koje „otkrivanje emocija smatra nepriličnim ... posebno kada se ona odnose na racionalističku legalnu maksimu da je naš sistem vladavina prava a ne ljudi. Kao da zakoni nisu proizvod ljudskih emocija. “39

Javni je sentiment, kako nam to dokazuje $\boldsymbol{A}$. Sajó, strukturalno drugačiji od „individualno (moralnih) emocija koji ga čine: on je mnogo više od njihove agregacije“. Javni sentimenti mogu imati temeljnu ulogu u trenutku ustavotvorstva, ali oni utječu na razvitak konstitucionalizma i nakon usvajanja ustava. Na djelu je dvotračni put. Naime...

... nakon što je inicijalni izbor javnih sentimenata dobio svoje mjesto u ustavu, izbor započinje utjecati kako na legalne odluke tako i na javne sentimente u njihovoj konstantnoj formulaciji. Državne institucije mogu izravno (putem pravila) i strukturalno (pomoću institucionalnih aranžmana koji oblikuju ljudske odnose) oblikovati emocije u njihovoj interakciji u javnim sentimentima. ${ }^{40}$

Najuvjerljivija su ilustracija Sajovih stajališta i njihova aplikacija prikaz i analiza opće atmosfere koja prati događaje prije i nakon usvajanja Deklaracije iz 1789. Povijesna rekonstrukcija tih događaja otkriva dramatični emocionalni naboj rasprava koje su pratile usvajanje revolucionarnih dokumenata ustavnog karaktera: strah od događaja izvan Pariza, pritisak s galerija skupštine, očajna akustika koja je onemogućavala bilo koju snošljivu komunikaciju, kaskade fragmentarnih i preklapajućih emocija koje su vodile govornike (taština izmiješana s kompleksima potisnute inferiornosti, ljubomora, mržnja i skorojevićevske frustracije delegata Trećeg staleža, velikodušno ushićenje plemstva koje se odricalo svojih ranijih privilegija (u sjeni straha i nepovjerenja), opća histerija itd. Može li se dakle izbjeći zaključku da ustavna pravila znači nisu samo svjesna kreacija apstraktnog racionaliteta nego ičinjenica koje su sastavni nusprodukt suprotstavljenih kolektivnih emocija? Prema A. Sajovoj rekonstrukciji događaja, abolicija feudalizma i konačna agregacija pravila koja čine ,stubove modernog konstitucionalizma... pravna jednakost, opće i srazmjerno oporezivanje, pravosuđe bez financijskih pristojbi, pristup javnoj službi, i vladavina prava“ zapravo su eruptirali posve slučajno iz „lonca za taljenje zajedničkih emocija“. ${ }^{41}$

39 András Sajó, CONSTITUTIONAL SENTIMENTS, Yale University Press. New Haven and London, 2010., p. 78.

40 András Sajó, op. cit., p. 58

${ }^{41}$ András Sajó, op. cit., p. 58. 
Sajov pogled na Ustav SAD-a i debate u Philadelphiji koji „reflektiraju selekciju emocionalnog iskustva zajednice“ ekstenzivno počiva na nalazima psihologije i neurologije kako bi pokazao da ,značenja koja se pripisuju događajima strukturirana u emocionalnim pojmovima“ $i$ koja su pohranjena kao „hladni sentiment" mogu biti prenesena drugima dugo nakon zbivanja koji su inicirali sentimente i to zahvaljujući „zrcaljenju“ neuralnog procesa. Na zatvorenim skupovima, kao što su ustavotvorni odbori/skupštine i zahvaljujući različitim kognitivnim napetostima, takvi se procesi pojačavaju ili iskrivljuju. Među piscima Ustava SAD-a prevladavajuća emocija između 1787. i 1791. bio je „strah“. 42

Brojne su i fascinantne i druge emocionalno-ustavne teme o kojima govori A. Sajó. Npr. abolicionizam čija je povijest uvelike doprinos empatiji koja funkcionira protiv zrna razuma: „Povijest abolicionizma je povijest pogreške u primjeni apstraktnog koncepta slobode. Abolicija kako se je desila bila je više ad hoc reakcija na patnju“; ${ }^{43}$ sloboda govora koja je ustavno zaštićena kao sloboda racionalnog izražavanja: „Sloboda govora se u mnogim prilikama prikazuje kao antiemocionalna institucija, uspješna separacija razuma od emocije"; ${ }^{44}$ sloboda okupljanja u smislu konceptualizacije okupljanja u racionaliziranu paradigmu gdje potraga za ustavnom genealogijom prava na slobodno okupljanje otkriva značaj usporedne evolucije preventivnih manje brutalnih sredstava policijske kontrole i zatočenja za ovu slobodu; ${ }^{45}$ ljudski sram kao ustavni sentiment koji ,,može generirati priznavanje odgovornosti“, i čija efikasnost počiva na „učinkovitosti izlaganja“ ali koji sve manje i manje funkcionira u naglašeno individualističkoj i samoizlagajućoj kulturi (kroz kreiranje profila web-persona, blogove, facebookove itd.).

Ergo, A. Sajó nam pokazuje da sentimenti i pretpostavke o njima imaju važno mjesto i ulogu u ustavnom uređenju i njegovu tumačenju. Također ističe i to da ustavna rješenja imaju utjecaja na socijalne emocije. Neuvažavanje interrelacije između emocija i drugih kognitivnih oblika optužuje pravnu teoriju za jednostranost što napori biheviorističke ekonomije uopće ne demantiraju. To pisac u Constitutional Sentiments objašnjava prisustvom straha u stvaranju brojnih ustava. Na tragu ovog mišljenja ustavi se stvaraju da bi pružili sigurnost od straha koji proizlazi, između ostaloga, i iz predustavnog razdoblja, pritiska i vladavine

42 ,The overarching theme of the Constitution of the United States, and the ,who's to say/where do you draw the line/thin edge of the wedge/parade of horribles/foot in the door/slippery slope, rhetoric it has engendered, is on of fear, a fear that in 1787 and 1791 was properly aimed at the state." F.Schauer, THE CONSTITUTION OF FEAR, 12 Const. Comment, 203, 1995.; F. Schauer, Constitutions of Hope and Fear, book review: Citizens Divided: Campaign Finance Reform and the Constitution, by R. C. Post, Cambridge, MA, Harvard Univ. Press, 2014., pp. 264.

43 A. Sajó, op. cit., p. 15 et passim.

44 A. Sajó, op. cit., p. 193.

45 A. Sajó, op. cit., p. 246. 
rulje, te strastvenog strančarenja. Emocije su strukturirala i ljudska prava: samilost i indignacija služe kao emocionalni temelji prihvaćanja i zahtijevanja ljudskih prava. Pojednostavljena verzija moderniteta nam poručuje da sve oko prava i ustavnog uređenja počiva na racionalitetu. U tom smislu Sajova teorija ustavnih sentimenata rekonstruira pretpostavke o ljudskoj prirodi kao emocionalnoj prirodi koja oblikuje ustav i njegovu interpretaciju. Međutim, paradigmatske promjene $\mathrm{u}$ ustavnom pravu ne mogu se objasniti bez uvida u dramatiku emocija i njihovog učinka za pravo. ${ }^{46}$

\section{KONSTITUCIONALIZACIJA PATRIOTIZMA U USTAVNODEMOKRATSKOJ DRŽAVI SUVREMENOG POSTANJA}

Pod pojmom konstitucionalizacije misli se na one argumente, principe i procedure koji se u određenoj sredini i u određenom vremenu koriste u definiranju prirode najvišeg zakona zemlje i promoviranju strategija ograničavanja javnih vlasti i zaštite individualnih prava. Ako je konstitucionalizacija ,proces konstrukcije datog ustavnog poretka“" ${ }^{47}$ onda je Ustav repozitorij promjenljivih kulturalnih vrijednosti. S obzirom na to da iz Ustava emaniraju normativne preferencije do kojih drži određena kultura u određenom vremenu, one dobivaju auru temeljnih ili transcedentnih vrijednosti. Za proces transformiranja normativnih preferencija u ustavno pravo presudnu ulogu imaju ustavotvorci i sudovi. Danas se smatra zastarjelim stajalištem da Ustav propisuje vrijednosti koje su neovisne o dominantnim kulturnim vrednotama. Kako je ustavni dokument kao „pisani akt najveće pravne snage koji prvenstveno regulira osnove“, ali ne sve osnove i ne samo osnove datog državnog i društvenog uređenja, počesto neprecizan, njegov je jezik počesto apstraktan, te je potreba za njegovim tumačenjem gotovo samorazumljiva. ${ }^{48}$ U tom smislu ustavno pravo se afirmira kao praksa generiranja ustavnog značenja iz normativnih preferencija ustavotvorne vlasti.

46 A. SAJÓ, Constitutional Sentiments, Acta Juridica Hungarica (C) 2006 Akadémiai Kiadó, Budapest 47, No 1, pp. 1-13 (2006.), DOI: 10.1556/AJur.47.2006.1.1, p. 1; M. C. Nussbaum, Political Emotions - Why Love Matters for Justice, Harvard Univ. Press, 2013., p. 480, M. C. Nussbaum, Toward a globally sensitive patriotism, http://ethics.crassh.cam.ac.uk/toward-a-globally-sensitive-patriotismmartha-c-nussbaum/;M. C. Nussbaum, Patriotism and Cosmopolitanism, http://bostonreview.net/ martha-nussbaum-patriotism-and-cosmopolitanism

47 Pennock, J. R. and J. W. Chapman (eds.), 1979., Constitutionalism, Nomos XX, New York, New York University Press, cit. pr. S. Fabbrini, Constitutionalization as an Open Process: Constituting Compound Polities From Philadelphia to Brussels, Lectio magistralis held in occasion of the „XII European Amalfi Prize for Social Sciences”, Amalfi, May 27, 2006.

48 M. Jovičić, O USTAVU, Beograd, 1977. 
Tijekom 19. i 20. stoljeća praksa donošenja formalnog ustava postala je opće pravilo moderne politike. Od Ustava se očekivalo da ima dvije uloge: institucionalnu i fundacionalnu. Prva - institucionalna - imala je funkciju uspostavljanja legalne i političke strukture institucija vlasti i procedure budućeg zakonodavstva. Ovdje je riječ o postavljanju legalnih granica državnoj vlasti. No, ustavi su dobili još jednu ulogu i to onu prema kojoj ustavni dokumenti...

... služe kao obvezujući dokument aspiracija koje narod ima za sebe kao naciju. U tom smislu njegov tekst može ocrtavati oblik zajednice njezinih tvoraca/subjekata kakvom ona želi postati: i to ne samo u smislu određenih struktura, procedura i temeljnih prava, već i njihovih ciljeva, ideala i moralnih standarda pomoću kojih oni žele da i drugi, uključujući tu i vlastito potomstvo, procjenjuju zajednicu... Ukoliko ustavni tekst nije 'sukladan s' idealima koji oblikuju ili koji će preoblikovati narod i tako izraziti politički karakter koji imaju ili koji bi željeli steći, takav će tekst vrlo brzo izgubiti snagu. ${ }^{49}$

Ta druga - fundacionalna funkcija ustava sastoji se u tome što oni, da bi bili prihvaćeni kao legitimni od naroda, moraju izraziti postojeću zajedničku viziju zajednice. U tom cilju, ustavi imaju ključnu ulogu u reprezentiranju ultimativnih ciljevaizajedničkih vrijednostikoje podupirudržavu. Ustavi su tako, razgraničavajući prihvaćene temeljne socijetalne norme i aspiracije naroda, osiguravali građanima osjećaj autorstva i vlasništva, naime osjećaj da „Mi Narod“ uključuje i svakog čovjeka ponaosob. Formalni je izraz ove fundacijske uloge ustava ovisio o tipu nacionalnog identiteta koji se očekivao biti predstavljen u ustavu. Drugim riječima, to je ovisilo o značenju fraze „Mi Narod“ koja se najčešće nalazila u preambulama modernih ustava. ${ }^{50} \mathrm{Na}$ fundacijskoj razini, ustavnu imaginaciju zapadnog svijeta činile su dvije ustavne paradigme koje su predstavljale dva različita tipa nacionalnog identiteta i koje su manifestirale dva različita razumijevanja odnosa između ustava i „naroda“. Prvi tip je esencijalistički ustav ili ustav države-nacije koji reflektira postojeće aspiracije, kulturu i vizije društva nizom deklaracija koje, između ostalih funkcija, štite vrijednosti od nacionalnog značaja (primjerice nacionalni jezik ili državnu religiju). Drugi tip je liberalni ustav koji izražava zajednički građanski identitet građanstva kroz formalizaciju temeljnih pravila koji omogućuju demokratsku participaciju, reprezentaciju i odlučivanje. Dok je prvi tip ustava primjer u kojemu se patriotizam doslovno konstitucionalizira - ovdje se briga za

49 W. F. Murphy, CONSTITUTIONS, CONSTITUTIONALISM AND DEMOCRACY, u: CONSTITUTIONALISM AND DEMOCRACY - TRANSITIONS IN THE CONTEMPORARY WORLD, ed. By D. Grenberg et al., Oxford Univ. Press, 1993., p. 10.

50 Andrew G. I. Kilberg, WE THE PEOPLE: THE ORIGINAL MEANING OF POPULAR SOVEREIGNTY, Virginia Law Review, Vol. 100, 2014., p. 1060-1109. 
ustav ad litteram predaje na „,̌uvanje patriotizmu svih svojih državljana“51 - drugi je model konstitucionaliziranje patriotizma povjerio sudovima. ${ }^{52}$ Najrječitiju potvrdu te tvrdnje predstavlja „proces juridifikacije“ u kojemu posebno mjesto, ulogu i značaj imaju Vrhovni sud SAD-a ${ }^{53}$ Savezni ustavni sud SR Njemačke, Europski sud za ljudska prava u Strasbourgu, te Europski sud pravde u Luksemburgu. ${ }^{54}$

4.1. Ustav SAD-a (1787.) i značenje privrženosti ustavu (constitutional attachment). O promjenjivim značenjima patriotizma i njegovom ustavnom kapacitetu govori i suvremeni američki konstitucionalist Sanford Levinson (1941.). U raspravi Constitutional Faith (1988.) Levinson nastoji odgovoriti na pitanje o tome koju to političku obvezu treba zadovoljiti stranac prije nego li se u statusu građanina priključi američkoj zajednici. ${ }^{55}$ Aktualizirajući problematiku naturalizacije iz predmeta Schneiderman v. United States (1943.), ${ }^{56}$ S. Levinson govori o postupku u kojemu se pojedinac „oslobađa starih lojalnosti i pristaje biti lojalan američkom državljanstvu“. No, Levinson smatra da se identificiranje s osjećajima koje vezuje uz američko državljanstvo kao „ulazak u odnos koji ljude vezuje odanošću određenim osjećajima i idealima sažetim u zahtjevu da su oni priključeni načelima Ustava“, po intenzitetu osjećaja ne može tek tako identificirati s „ordinarnim patriotizmom“ kao pukom „ljubavi prema domovini“. Njihovi su sentimenti mnogo kompleksniji. Naime, njegova posvećenost domovini prolazi

51 Riječ je o Ustavu Francuske II. Republike (1848.) koji je doslovno sadržavao sljedeću odredbu: Article 110. - L'Assemblée nationale confie le dépôt de la présente Constitution, et des droits qu'elle consacre, à la garde et au patriotisme de tous les Français. Usp. Constitution de 1848, IIe République, CHAPITRE X - DISPOSITIONS PARTICULIERES: Article 108. - La Légion d'honneur est maintenue; ses statuts seront révisés et mis en harmonie avec la Constitution; Article 109. - Le territoire de l'Algérie et des colonies est déclaré territoire français, et sera régi par des lois particulières jusqu'à ce qu'une loi spéciale les place sous le régime de la présente Constitution; Article 110. - L'Assemblée nationale confie le dépôt de la présente Constitution, et des droits qu'elle consacre, à la garde et au patriotisme de tous les Français.

52 S. Levinson, Assessing the Supreme Court's Current Caseload: A Question of Law or Politics?, 119 Yale L. J. Online 99 (2010), available at http://yalelawjournal.org/forum/assessing-the-supremecourts-current-caseload-a-question-of-law-or-politics.

53 S. Levinson, CONSTITUTIONAL FAITH, Princeton University Press, 1988., p. 1-250.1; J. M. Balkin, SANFORD LEVINSON'S SECOND THOUGHTS ABOUT CONSTITUTION FAITH, Tulsa Law Review, Vol. 48, 2012., p. 101-117.

54 M. Hailbronner, Traditions and Transformations: The Rise of German Constitutionalism, Oxford University Press, 2015., M. Hailbronner, Rethinking the rise of the German Constitutional Court: From anti-Nazism to value formalism I•CON (2014.), Vol. 12 No. 3, 626-649; o procesu konstitucionalizacije u EU kontekstu v. A. von Bogdany (ed.) PRINCIPLES OF EUROPEAN CONSTITUTIONAL LAW, Oxford 2006., p. 217; C. Barnard, CITIZENSHIP OF THE UNION AND AREA OF JUSTICE: (ALMOST) THE COURT'S MOMENT OF GLORY, "Citizenship of the Union and the Area of Justice: (Almost) The Court's Moment of Glory" in: A. Rosas, E. Levits and Y. Bot, The Court of Justice and the Construction of Europe: Analyses and perspectives on Sixty Years of Case Law (Asser press) (Ed).

55 S. Levinson, CONSTITUTIONAL FAITH, Princeton University Press, 1988., p. 1-250.

56 Schneiderman v. United States 320 U.S. 118 (1943.), https://supreme.justia. com/cases/federal/us /320/118/ case.html 
kroz proces identifikacije $s$ nečim što bi se moglo smatrati njezinim najvišim idealima. ${ }^{57}$

Za Levinsonovu generaciju značenje patriotizma je već bilo drugačije. Smatralo se npr. da je patriotizam u smislu ,ljubavi prema domovini“" uvelike bio zaprljan američkom intervencijom u Vijetnamu. „Novi patriotizam“, kako ga je kasnije promovirao npr. R. Reagan, služio je samo potvrdi sumnji o ,takvoj“ ljubavi prema domovini.

Temeljno pitanje na koje pokušava odgovoriti S. Levinson jest pitanje o tome što zapravo konstituira Ustav kao objekt određenih ,javnih zaloga i obožavanja“. U tom pravcu koristeći Schneidermana, on posebno propituje mjesto, ulogu i pravi sadržaj prisege na Ustav. Pri tome su temeljna dva sljedeća pitanja: Što ustvari znači kad netko objavljuje svoju vjernost Ustavu ili govori o svojoj „vjeri u Ustav? Koje je zapravo značenje ,privrženosti“ (attachment) o kojoj govori Ustav SAD-a? ${ }^{58}$ U corpusu američkog ustavnog prava ne postoji - naglašava Levinson - predmet poput Schneiderman v. United States (1943.) ${ }^{59}$ i to zato jer se ovdje „,Sud našao na onoj razini analize koja stavlja u pitanje i sami identitet interpretiranog Ustava“.60 Odnosi li se ,privrženost“ jednostavno na manifestirano ponašanje ili na unutarnje stanje svijesti i mentalne dispozicije?

Sudac Frank Murphy (1890. - 1949.) koji je Schneidermanu pisao odluku u ime većine (5) raspravljao je o tome što znači biti privržen Ustavu SAD-a sa stajališta

57 S. Levinson, CONSTITUTIONAL FAITH, Princeton University Press, 1988., p. 1-250.1; J. M. Balkin, SANFORD LEVINSON'S SECOND THOUGHTS ABOUT CONSTITUTION FAITH, Tulsa Law Review, Vol. 48, 2012., p. 101-117.

58 S. Levinson, op. cit., p. 126-127.

59 William Schneiderman postao je naturalizirani građanin SAD-a tijekom 1927. godine. U to vrijeme bio je aktivni član Američke radničke partije i Američke lige mladih radnika (komunista). U prijavi kojom je zatražio državljanstvo napisao je bilješku da je ,živio kao osoba koja je privržena principima Ustava SAD-a“, što je bio zakonski uvjet da se kao državljanin uđe u SAD kao državnu i političku zajednicu. Dvanaest godina kasnije (1939.) SAD je pokušao otkazati Schneidermanovu svjedožbu o državljanstvu temeljem tvrdnje da je njegov certifikat bio pribavljen ilegalno. Za vlasti je njegova komunistička aktivnost manifestirala ponašanje koje nije bilo konzistentno s njegovim zavjetom ustavnom attachmentu. Federalni područni sud u Kaliforniji presudio je u korist Države te mu je uskratio državljanstvo. Nakon što je tu odluku podržao i Žalbeni sud, W. S. se žalio Vrhovnom sudu SAD-a. Većina je preko suca Murphyja naglasila da je krucijalna okolnost proceduralno pitanje: vlast je pokušavala ukinuti odluku „godinama nakon što je državljanstvo već bilo dodijeljeno“. Riječ je zapravo o pokušaju da se Schneidermanu opozove državljanstvo SAD-a zbog njegovog članstva u Komunističkoj stranci SAD-a, koja je navodno djelovala protiv principa Ustava i koja zagovara nasilno svrgavanje američke vlade. Sud je presudio da je Država propustila na zadovoljavajući način pokazati da tuženik nije privržen načelima Ustava SAD-a, niti je na zadovoljavajući način dokazala da je tijekom 1927. godine Komunistička stranka SAD-a zagovarala takvu upotrebu nasilja da bi ona stvorila jasnu i neposrednu opasnost. Sud je presudio za Schneidermana, utvrđujući da „očevi utemeljivači, i sami revolucionari, nisu budućim generacijama skrojili nikakvu luđačku košulju“; prije se može reći da su štitili slobodu misli iz I. Amandmana. Usp. Schneiderman v. United States 320 U.S. 118 (1943.), https://shprs.clas.asu.edu/sites/ default/ files/ Schneiderman_v_US.pdf; Schneiderman v. United States 320 U.S. 118 (1943.) https:// supreme. justia. com/cases/ fēeral/us/ 320/118/case.html

60 S. Levinson, op. cit., 127. 
I. Amandmana. Sudac je, s obzirom na komunističke dokumente koji su pozivali na aboliciju privatnog vlasništva bez naknade, izgradnju diktature proletarijata u kojoj su se uskraćivala politička prava onih koji nisu bili proleteri i/ili članovi Partije, kao i na stvaranje međunarodnog saveza sovjetskih republika itd., zaključio da sljedba spomenutih doktrina ne znači nužno da netko nije privržen i načelima Ustava SAD-a. Imajući u vidu promjene toga Ustava, on je dokazivao kako su promjene učinjene Amandmanom V. (1791. $)^{61}$ i drugim dalekosežnim promjenama nakon 1787. god. odbacivale ideju - „da je nečija privrženost bilo kojoj posebnoj odredbi ili odredbama od suštinskog značaja, ili da netko tko zagovara radikalne promjene ne bi nužno bio i privržen Ustavu“. ${ }^{62}$

Sudac William O. Douglas je dokazivao (concurring opinion) da se Zakon o državljanstvu iz 1906. trebao interpretirati tako da se opoziv državljanstva mogao tražiti jedino temeljem prijevare; sudac Wiley Routledge je također u svom pridruženom mišljenju tvrdio da bi opoziv S. državljanstva rezultirao stalnim dvoklasnim sistemom državljanstva, u kojemu bi naturalizirani američki državljani stalno živjeli u strahu od deportacije; Chief Justice Harlan Fiske Stone je u svom protivnom mišljenju (dissenting opinionu), koje su podržavali suci $\boldsymbol{F}$. Frankfurter i $\boldsymbol{O}$. Roberts, izrazio uvjerenje o postojanju hijerarhije ustavnih načela te da privrženost Ustavu znači vjeru u određena načela Ustava - koje on definira kao...

,... načela zaštite građanskih prava te života, slobode i vlasništva, načelo predstavničke vlade, te načelo da se ustavni zakoni ne slamaju planiranim neposluhom... Pretpostavljam da su sva načela Ustava neprijateljska prema diktaturi i vladavini manjine, jer je princip našeg Ustava da se promjena organizacije naše vlade može odvijati jedino redovnim procedurama koje određuje Ustav a ne silom ili prijevarom. ${ }^{\text {"“3 }}$

Mišljenju predsjednika Vrhovnog suda priključio se i sudac $\boldsymbol{F}$. Frankfurter koji je svojim osobnim iskustvom svjedočio o „privrženosti ustavnim načelima“.

61 „Nitko ne može biti pozvan na odgovornost za kazneno djelo kažnjivo smrću ili drugo teško kazneno djelo, osim na temelju prijave ili optužnice koju je podigla Velika porota, osim za kaznena djela počinjena u kopnenim ili pomorskim snagama, ili u miliciji za vrijeme aktivne službe u doba rata ili javne opasnosti; nitko ne smije biti dva puta kazneno gonjen za isto kazneno djelo; niti se smije siliti da u bilo kojem kaznenom suđenju svjedoči sam protiv sebe, niti lišavati života, slobode ili imovine bez pravičnog sudskog postupka, niti se smije oduzeti privatna imovina za javnu upotrebu bez pravedne naknade."Am. V. (1791).

62 Schneiderman v. United States 320 U.S. 118 (1943.), https://supreme.justia. com/cases/federal/us /320/118/ case.html

63 United States Supreme Court SCHNEIDERMAN v. UNITED STATES (1943.) No. 1353, Argued: March 12, 1943 Decided: June 21, 1943 - See more at: http://caselaw.findlaw.com/us-supremecourt/320/118.html\#sthash. R8QzuDmv.dpuf 
... Privrženost Ustavu je povijesna fraza stoga nije prazna od svih mogućih značenja - nije dakle puka retorička rascvjetanost - te sasvim izvjesno ne znači da ste privrženi načelima Ustava ako želite zbaciti šemu društva kojemu je Ustav okvir iz jednostavnog razloga što postoji pravo da se jedno od načela promijeni. Drugim riječima, teško da netko može biti privržen Ustavu samo zato što je netko spreman poništiti Ustav a on mu omogućuje sredstva da se to učini. ${ }^{64}$

Razlika koja se u Schneidermanu pojavila između većine i manjine tako je još jednom u novim okolnostima otvorila pitanje o središnjem paradoksu američkog konstitucionalizma, naime postojanju jednog takvog zaključka...

... koji omogućuje legitimiranje djelovanja koje se inače može protumačiti kao ilegalno i neustavno. Odatle proizlazi da „dobrog Amerikanca“ ne čini samo pokoravanje pravu, to ne samo da nije ni dovoljan uvjet, to čak ne mora biti ni nužan uvjet. ${ }^{65}$

Ne ulazeći u teška i otvorena pitanja filozofije i procjene političkog djelovanja, većina je u Sudu preko J. Murphyja zapravo odbacila specifikacije tzv. propozicijskog Ustava (constitutional propositionalism) iza kojeg je stajalo Ministarstvo pravosuđa. ${ }^{66}$ Pozivajući se na suca $\boldsymbol{O}$. W. Holmesa, on identificira ono načelo Ustava koje imperativnije nego bilo koje drugo načelo poziva na privrženost Ustavu, naime na ,načelo slobode misli“ iz I. Amandmana (1791.), a čiji se prostor tolerancije širi i na ,misao koju mrzimo“. ${ }^{67}$

Kao sudac koji je bio osjetljiviji prema pitanju građanskih sloboda i zaštiti onih koji drugačije misle, Murphy je oštro odbacivao svaku pomisao da bi naturalizacija pripadala samo ,onima čiji politički pogledi koincidiraju s onim što najboljim su

64 Ibidem.

65 S. Levinson, op. cit., p. 129.

66 „Test je zapravo sljedeći ... da li (podnositelj zahtjeva) substituira revoluciju za evoluciju, destrukciju za konstrukciju, da li on vjeruje u uređeno društvo, vladavinu zakona, prema kojoj narod daje vladi ovlasti koje štite prava i slobode pojedinca i manjina a koje im većina ne može oduzeti; da li, u konačnici, događaji koji sežu ne dalje od Deklaracije o neovisnosti, koju slijedi Revolucionarni rat usvajanje Ustava, uspostavljaju principe koji poštuju vlast, pojedinca, manjinu i većinu, kojim je uređena sloboda zamijenila dezorganiziranu slobodu." Usp. Schneiderman v. United States 320 U.S. 118 (1943.) https:// supreme. justia.com/cases/ federal/us/ 320/118/case.html; cit. pr. S. Levinson, p. 136.

67 ,Surely it cannot show lack of attachment to the principles of the Constitution that she thinks that it can be improved. I suppose that most intelligent people think that it might be. Some of her answers might excite popular prejudice, but if there is any principle of the Constitution that more imperatively calls for attachment than any other it is the principle of free thought-not free thought for those who agree with us but freedom for the thought that we hate. I would suggest that the Quakers have done their share to make the country what it is, that many citizens agree with the applicant's belief and that I had not supposed hitherto that we regretted our inability to expel them because they believed more than some of us do in the teachings of the Sermon on the Mount.“ O. W. Holmes, Dissenting opinion, United States v. Schwimmer, 279 U.S. 644 (1929.). 
smatrali kako očevi utemeljivači 1787. godine tako i oni koji danas predstavljaju većinu u ovoj zemlji““. ${ }^{68}$ Jer, kad bi bilo suprotno, onda bi se i za Lincolna zbog Emancipation Proclamation (1863.) i XIII. Am. (1865.) moglo sumnjati u njegovu privrženost Ustavu. ${ }^{69}$

No, ipak je činjenica da je $\boldsymbol{A}$. Lincoln s vremenom dobio „suštinski sporni“ (essentially contested) status unutar američke političke misli. Ličnost o kojoj se najviše pisalo u američkoj povijesti inkarnira zapravo svekolike tenzije „lidera koji pokušava živjeti svoje nacionalne odgovornosti uz istovremeno nastojanje da bude vjeran svojoj svečanoj prisezi da djeluje unutar ustavnih ograničenja“. ${ }^{70}$ Život A. Lincolna, poput Schneidermanovog, prisiljava nas da se konfrontiramo s , apsolutno temeljnim pitanjima“" o prirodi američkog Ustava; doći do konsenzusa o Lincolnu značilo bi doći do konsenzusa o samom Ustavu; a Levinson u Constitutional Faith argumentira kako je svaka potraga za bilo kakvim konsenzusom o tom pitanju sasvim himerična. Ipak, uprkos svim poteškoćama, Lincolnovo shvaćanje konstitucionalizma treba tražiti u afirmaciji ljudskog dostojanstva kao najvažnijem ograničenju vrijednosti većinske vladavine, dakle onome što na ultimativni način „,inkarnira vrijednost hijerarhijski superiorniju od takve vladavine““. ${ }^{71}$

Središnja je Levinsonova tema zapravo istraživanje ideje o ustavu kao američkoj „civilnoj religiji“. On nam pojašnjava dvosmislenosti „vjere u Ustav“ kao duboke privrženosti Ustavu koji je središte političkog života određenog pojedinca $\mathrm{i}$, naravno, nacije. Levinson pritom ne slijedi onu vrst linearnog argumenta koji nas vodi do samorazumljivih neizbježnih zaključaka koji se inače mogu naći u suvremenoj ustavnopravnoj misli. On prije nudi seriju razmišljanja o međupovezanim aspektima ustavne vjere. U tom smjeru on dokazuje da je najveći broj tumača Ustava kao „civilne religije“ propustio istaći njene najznačajnije strane jer su naglašavali ,integrativnu funkciju“ Ustava i njegovu simboliku davanja „sveobuhvatnog osjećaja jedinstva čak i društvu razbijenog konfliktom“. ${ }^{72}$ Takav pristup - kaže Levinson - previđa činjenicu da je u posljednjih 500 godina religija prije služila kao razlog dubokih podjela nego jedinstva. Zato nas ne čudi zaključak da

68 S. Levinson, op. cit., p. 137.

69 „Prvog siječnja 1863., u vrijeme dok se nacija približava trećoj godini krvavog građanskog rata, predsjednik Abraham Lincoln izdao je Proklamaciju o emancipaciji. U toj se proklamaciji objavilo osobođenje „svih osoba koje su se u pobunjenim državama držale kao robovi“. EMANCIPATION PROCLAMATION, https://www.archives. gov/exhibits/featured_documents/ emancipation proclamation/; Amendment XIII, USA (1865.): Section 1. Neither slavery nor involuntary servitude, except as a punishment for crime whereof the party shall have been duly convicted, shall exist within the United States, or any place subject to their jurisdiction. Section 2. Congress shall have power to enforce this article by appropriate legislation.

70 S. Levinson, op. cit., p. 139.

71 S. Levinson, op. cit., p. 150.

72 D. Kennedy, AMERICAN CONSTITUTIONALISM AS A CIVIL RELIGION: NOTES OF AM ATHEIST, Nova Law Review, Vol. 19, 1995., p. 909-921. 
tradicionalni izvori religijskih podjela imaju paralele u brojnim klasičnim ustavnim kontroverzama. Takva je i ona o smislu i sadržaju ustavne prisege i lojalnosti.

Fokusiranje na specifični sadržaj prisege o lojalnosti priziva snažnu analogiju s religijom koja postavlja pitanje: treba li vjernost Ustavu mjeriti prema određenom unutrašnjem stanju (inner faith) ili vidljivom ponašanju (good works)? Ako se fokusiramo na ovo drugo - kako se onda mogu opravdati povrede prava koje su počinile najveće figure u Panteonu američkog konstitucionalizma - očevi federalizma u Philadelphiji i Abraham Lincoln, otac „drugog Ustava“, uvedenog nakon Građanskog rata? Poznato je da su „očevi ustavnosti“ J.Madison i A. Lincoln bili pokretači niza ilegalnih aktivnosti. Ratifikacija Ustava bila je ,jednostavno ne-legalna radnja“" (plainly an extra-legal) kojom su se vrijeđale odredbe prvog američkog (nacionalnog) ,ustava“ (Articles of Confederation). Lincolnova politika vojnih uhićenja suspenzijama habeas corpusa kršila je ustavna ograničenja, a glasovita Proklamacija o emancipaciji bila je jednako ustavnopravno suspektna. Znači li to da su radnje i akti kojima su Madison i Lincoln preoblikovali temeljno američko pravo otkrili nedostatak lojalnosti i iskrenosti prema naslijeđenom Ustavu? Nije li sama mogućnost zakonitog preoblikovanja američkog temeljnog zakona putem odredaba čl. V. Ustava, ${ }^{73}$ daljnja komplikacija pojma lojalnosti temeljnom dokumentu? Može li se netko uopće smatrati iskreno ,vjeran“ dokumentu ako, usprkos činjenici da ne podnosi nijedno suštinsko pravilo, ipak traži promjenu tih pravila samo kroz procedure čl. V.? To pitanje - zaključuje Levinson - povlači ujedno i temeljnu razliku između ustavnog prava i religije:

Jedna od vitalnih razlika između ustavne vjere i tradicionalnih religijskih uvjerenja jest baš eksplicitno autoriziran proces (ustavne) promjene. Najvažnije zapadne religije opirale su se teorijama „kontuiniranog otkrivenja“ koje su faktički mogle legitimizirati stroge ,,izmjene i dopune“ božje zapovijedi, a koje su zagovarale osobe koje su se pozivale na izravnu komunikaciju s Bogom. ${ }^{74}$

Primjer američkog Ustava i njegova konstitucionalizma prvi je razvijeni okvir zamjene religije i moralnosti (u obliku prirodnog prava) kao središnjeg izvora normativiteta i to na način da je osvojio poziciju ,simboličkog markera“

73 Article V: ,The Congress, whenever two thirds of both houses shall deem it necessary, shall propose amendments to this Constitution, or, on the application of the legislatures of two thirds of the several states, shall call a convention for proposing amendments, which, in either case, shall be valid to all intents and purposes, as part of this Constitution, when ratified by the legislatures of three fourths of the several states, or by conventions in three fourths thereof, as the one or the other mode of ratification may be proposed by the Congress; provided that no amendment which may be made prior to the year one thousand eight hundred and eight shall in any manner affect the first and fourth clauses in the ninth section of the first article; and that no state, without its consent, shall be deprived of its equal suffrage in the Senate." USA CONSTITUTION 1787, http://www.archives.gov/federal-register/constitution/article-v. html

74 S. Levinson, op. cit., p. 152. 
iz kojeg se deriviraju sve legalne norme. Ustav je postao fokus političkog života u pluralističkom društvu što je Rawls opisao kao overlapping consensus,$^{75}$ a $\mathbf{J}$. Habermas kao ustavni patriotizam.

Taj isti fokus političkog života u SAD-u ugrozio je ironijom sudbine akt koji slučajno nosi naziv Patriot Act što je akronim za zakon kojemu je puno ime Providing Appropriate Tools Required to Intercept and Obstruct Terrorism Act. Zakon je donio Kongres SAD-a 11. rujna 2001. i to neposredno nakon terorističkog napada na SAD. Potpisan od Predsjednika SAD-a 26. listopada 2001., Patriot Act je na 340 stranica zaprepastio civilizirani svijet prezirom i gaženjem brojnih ustavnih odredbi - uključujući slobode I. i IV. Amandmana dakle slobode govora i udruživanja i zabranu nezakonite pretrage i zapljene. Ovaj je drakonski zakon na izravan način ugrozio najvredniji američki legat slobode i privatnosti. Reakcije su ponovno pokazale da patriotizam predstavlja puno više od mahanja zastavama i paljenja pirotehnike. Najumniji Amerikanci tražili su odlučnu obranu fundamentalnih američkih principa pravde i slobode od nekontrolirane administracije $\boldsymbol{G}$. W. Busha. Poziv na restauraciju temeljnih kontrola i provjera (checks and balances) predstavlja najpodesniji oblik patriotizma koji danas trebaju građani najstarije i najuglednije ustavnodemokratske republike na svijetu. ${ }^{76}$

\section{POSTNACIONALNI KONSTITUCIONALIZAM I SMISAO USTAVNOG PATRIOTIZMA NOVOG TIPA}

Od sredine 20. stoljeća ustavna demokracija konfrontirala se s nekoliko izazova. Zapravo, konstitucionalizam (domestic constitutionalism) kao „glavno sidro“ političkog poretka u kojemu je ,nacionalna demokracija“ predstavljala vladajuću paradigmu 20. st. ubrzano se konfrontirao s trendovima koji su sve više potkopavali i izazivali tu vladajuću paradigmu. Oni su bili povezani s političkim kontekstom, ideološkim previranjima, identitetom zajednice te strukturom režima. Politički kontekst tiče se prijelaza prema nadirućem transnacionalnom tržišnom društvu, pitanje ideologije ima veze s novim tipom individualizma i politikom identiteta, pod zajednicom se više ne misli isključivo na homogenu naciju ili narod, a raniji hegemon parlamentarne demokracije više ne zadovoljava nove zahtjeve koji

75 J. Rawls, The Idea of an Overlapping Consensus, Oxford Journal of Legal Studies, Vol. 7, No. 1 (Spring, 1987), pp. 1-25.

76 K. Uhalova, The Patriot Act vs. the Constitution, http://www.kean.edu/ eslprog/accents/ 2006/ page2006_13.html; Z. Kaldveer, The Patriot Act and the Quiet Death of the US Bill of Rights, http:// www.commondreams.org/views/2011/06/20/patriot-act-and-quiet-death-us-bill-rights 
dolaze sa strane novih zajednica koje djeluju u novom političkom i ekonomskom kontekstu. $^{77}$

Nova je situacija stvarala veliki pritisak na klasične oblike konstitucionalizma kao „kamena temeljca zapadne političke imaginacije“ i međunarodnog prava. Tradicionalni je konstitucionalizam bio u neprilici jer su ključna pitanja razvoja sve više izmicala iz dosega nacionalnih ustava i nacionalnog političkog procesa. Novo međunarodno pravo i globalna vladavina (global governance) daleko su učinkovitije rješavali probleme s kojim se susretala nacionalna država u okolnostima novog međunarodnog poretka nakon Drugog svjetskog rata. Međunarodno pravo je pak doživljavalo probleme zbog uske legitimnosti koja se tradicionalno bazirala na traženju suglasnosti (consent-oriented legitimacy) i zbog ubrzanih procesa njegove fragmentacije, pluralizacije, vertikalizacije i privatizacije. ${ }^{78}$ Klasična distinkcija između domaćih i međunarodnih sfera uvelike se izmiješala, pa se umjesto ranijih, relativno jasnih pravila i kategorija javilo mnoštvo formalnih i neformalnih konekcija. U tom smislu pravo je - ,postalo 'postnacionalno' - nacionalna sfera je i dalje važna - ali ona više nije paradigmatsko sidro čitavoga poretka“. ${ }^{79}$ Odgovor na brojne probleme suvremenog svijeta traži se u konstitucionalizaciji međunarodnog

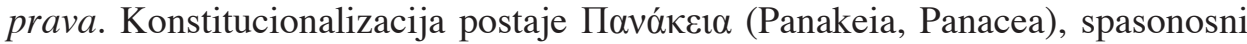
odgovor na fragmentaciju koji obećava jedinstvo globalnog poretka; stav koji na pluralizaciju odgovara s idejom centralizacije; a na vertikalizaciju odgovara s jasnom skupinom normativnih opredjeljenja. ${ }^{80}$

Konstitucionalizacija međunarodnog prava ili međunarodni konstitucionalizam postala je isto toliko važna tema koliko i tradicija „domaćeg“" konstitucionalizma. Prvi je počeo dominirati nad drugim. U tom je složenom fenomenu druge polovice 20. st. konstitucionalizacija EU postala poligon dinamične konfrontacije nacionalne države i institucija međunarodnog prava. $C$. Möller konstitucionalizaciju razumije kao „fenomen gradualne formacije novog legalnog poretka“. ${ }^{81}$ Za Erica Steina proces konstitucionalizacije EC (EU) započinje sudskim aktivizmom Europskog suda pravde (ECJ) koji svojim odlukama stvara i širi doktrine izravnog učinka, supremacije EU prava, europske legislative, implicitnih ovlasti. ${ }^{82}$ Fenomen sudski

77 L. Trägårdh (ed.), AFTER NATIONAL DEMOCRACY - RIGHTS, LAW AND POWER IN AMERICA AND THE NEW EUROPE, London, 2004., p. 1-8.

78 J. Klabbers et al., THE CONSTITUTIONALIZATIO OF INTERNATIONAL LAW, Oxford, 2009., p. 11 et passim.

79 N. Krisch, BEYOND CONSTITUTIONALISM - THE PLURALIST STRUCTURE OF POSTNATIONAL LAW, Oxford, 2010., p. 4.

80 J. Klabbers et al., op. cit. 23 et passim.

81 C. Möller, POUVOIR CONSTITUANT - CONSTITUTION-CONSTITUTIONALIZATION, u: A. von Bogdany (ed.) PRINCIPLES OF EUROPEAN CONSTITUTIONAL LAW, Oxford, 2006., p. 217.

82 E. Stein, LAWYERS, JUDGES AND THE MAKING OF A TRANSNATIONAL CONSTITUTION, u: American Journal of Inbternational Law, 17, 1981., p. 1-27. 
stvorenog ustava (judicially created constiutution) neizbježno je postavio i pitanje odnosa s mogućim pisanim ustavom EU?

5.1. Europski ustav i pitanje ustavnog patriotizma. Proces konstitucionalizacije EU otvorio je dva važna pitanja. Prvo je pitanje mogućnosti postojanja pisanog Ustava EU koji bi respektirao i kodificirao ,acquis communautaire constitutionnel“ i njegova odnosa prema „sudski stvorenom ustavu“. Drugo je pitanje govorilo o mogućnostima višerazinske vladavine i adekvatnom konstitucionalizmu (multilevel constitutionalism). I jedno i drugo pitanje doticali su se pitanja patriotizma.

Za J.H.H. Weilera ustavni etos modernosti i dalje iskazuje potrebu za ustavom, ali drugim tipom ustava, a onda, uključivo u tome, ima i poseban odnos prema temi patriotizma. Za Weilera „ustavni patriot je pozvan da brani ustav“. Ali zagovaranje europskog ustava nije zagovaranje pisanog ustavnog dokumenta koji su, uostalom, Francuzi i Nizozemci u obliku Treaty establishing a Constitution of Europe odbili 2005 godine. Ono što Europa treba jest princip ustavne tolerancije koja je za Weilera najvažnija europska ustavna inovacija. Sukladno tom načelu, ustavni akteri država članica prihvaćaju europsku ustavnu disciplinu i to ne zbog zahtjeva legalne doktrine kao što je slučaj u federalnoj državi, već zbog podvrgavanja višem suverenitetu i autoritetu i normama koje je osnažio udruženi ustavni demos. U slučaju dobrovoljnog prihvaćanja i subordiniranja, takav čin predstavlja , akt istinske slobode i emancipacije od kolektivne samo-arogancije i ustavnog fetišizma: riječ je o činu ustavne tolerancije“ ${ }^{83} \mathrm{U}$ akciji ustavne tolerancije afirmiraju se najbolje odlike europskog ustavnog patriotizma.

5.2. O mjestu i ulozi europskog ustavnog patriotizma. Više teoretičara ustavnog patriotizma (UP) dokazuje da se jaki sentiment nacionalnog identiteta što ga dijele državljani može zamijeniti vjernošću univerzalnim principima, koji se u konkretnim ustavnim okvirima stalno interpretiraju u otvorenoj javnoj debati. U Europi pojam ustavnog patriotizma ima njemačke korijene pa se u konvencionalnom smislu nadovezuje na problematiku nadilaženja iskustva njemačkog fašizma i holokausta. Tako se unutar prostora prevladavanja traumatskog povijesnog iskustva, nakon Drugog svjetskog rata postavilo pitanje ne samo o mogućnostima postojanja njemačkog identiteta nego i pitanje o tome kako se on može „sigurno“ konstituirati.

Nekoliko je pisaca zaslužno za prihvaćanje ove teme, najprije u njemačkom nacionalnom, a kasnije i u širem europskom kontekstu. Prema Jan-Werneru Mülleru, prve je inicijalne misli o idejama iz kojih ce se formulirati koncept ustavnog patriotizma dao filozof Karl Jaspers (1883. - 1967.) u svom eseju Pitanje

83 J. H. H. Weiler, FEDERALISM AND CONSTITUTIONALISM: EUROPE'S SONDERWEG, http:// jean monnetprogram.org/archive/papers/00/001001.html; J.H.H. Weiler, On the power of the Word: Europe's constitutional iconography, I.CON, Volume 3, Numbers 2 \& 3: Special Issue May, 2005., pp. 173-190. 
njemačke krivice (1947.) gdje se tvrdi da Njemačka ne može tek tako rekonstruirati svoj identitet. Da bi se to omogućilo, Nijemci moraju prihvatiti kolektivnu odgovornost za svoju prošlost jer bi se na „kontinuirano potiskivanom sjećanju“ mogli izgraditi temelji solidarnosti. Izravnu artikulaciju ustavnog patriotizma omogućio je Dolf Sternberger (1907. - 1989.) koji je pod Verfassungspatriotismus mislio na identificiranje građana s demokratskim ustavom koji bi oni bili spremni i braniti. Ovdje je ustavni patriotizam preuzeo oblik "militantne demokracije", naime onaj oblik liberalno demokratske vladavine koja će radi vlastite obrane biti netolerantna i boriti se protiv neliberalnih pokreta koji bi kompromitirali kvalitetu demokracije. Međutim, najelokventnije zagovaranje ustavnog patriotizma dao je Jürgen Habermas tijekom žive rasprave između njemačkih historičara („Historikerstreit”) kada je, nasuprot povjesničarima koji su zagovarali povratak osjećaju njemačkog nacionalnog ponosa, on prije zagovarao ustavni patriotizam kao alternativnu formu identiteta i pripadanja. ${ }^{84}$

Ustavni patriotizam, kako su ga shvaćali Habermas i drugi teoretičari, najšire se može definirati kao prihvaćanje zajedničke vladavine koja umjesto nacionalizma ili sličnih sentimenata dijeli zajedničko opredjeljenje prema ispravno oblikovanim načelima kao najobranjivijim sredstvima povezivanja zajednice. Ustavni patriotizam pruža potencijal za političku integraciju s onima s kojima se nema zajednički identitet i djeluje kao proces skidanja nacionalnog identiteta s institucija i praksi koje čine osnovu demokratske zajednice. Njegovi pristalice privrženi su općim (liberalno) demokratskim principima koje građani opravdavaju onim ustavnim tumačenjem koja najbolje reflektiraju njihov partikularni kontekst - prije svega želju građana o tome kako da žive zajedno. U tom pogledu, ustavni se patriotizam teorijski promišlja kao model legitimiteta koji ovisi koliko o normativnom legitimitetu toliko i o legitimitetu koji proizlazi iz formirane kolektivne volje. On se nadalje promišlja ne samo kao vjernost apstraktnim i univerzalnim principima nego i kao proces raspravljanja o sadržaju specifičnog ustava putem kojega se ta vjernost objavljuje; ustav će biti ne samo mjesto ,intenzivnog ali razumno moralnog i političkog osporavanja“ već će i oblikovati osnovu opravdavanja prisilne prakse partikularne države. ${ }^{85}$

84 Z. Posavec, Napomena o patriotizmu, domovini i nacionalizmu, Polit. misao, Vol XXXVIII, (2001.), br. 2, str. 111-112; D. Sternberger, Pojam domovine, Polit. misao, Vol XXXVIII, (2001.), br. 2, str. 113-124; J. Habermas, Povijesna svijest i posttradicijski identitet. Zapadna orijentacija Savezne Republike Njemačke, Polit. misao, Vol XXXVIII, (2001.), br. 2, str. 125-136; J. W. Müller (2004.), Is Euro-Patriotism Possible? Dissent Magazine [online]. http://www.dissent magazine. org/ article/ ?article=364; J. W. Müller, Constitutional Patriotism. Princeton University Press, 2009., 192 pages; J. W. Müller, Is Europe Converging on Constitutional Patriotism? (And If So: Is It Justified?' Critical Review of International Social and Political Philosophy. 10 (3): 377-387; J. W. Müller (2008.), A European Constitutional Patriotism? The Case Restated. European Law Journal. 14 (5): 542-557.

85 J. W. Müller, Constitutional Patriotism. Princeton, 2009., p. 15-46. 
5.3. Odnos ustavnog patriotizma i nacionalizma. Ideja ustavnog patriotizma od početka je bila robustna alternativa integraciji koja se temeljila na nacionalizmu. Na to upućuje nekoliko mogućih kritika. Prva se fokusira na osjetljivost inzistiranja nacionalizma na argument da je nacionalnost koju imaju državljani nužna za učinkovitu demokratsku praksu i cjelovito funkcionirajuću državu blagostanja, ili da je nacionalizam nužan za ostvarivanje jake forme savjetodavne demokracije. Međutim, evidentno je da su demokracija i država blagostanja mogući i u odsustvu zajedničkog kulturnog identiteta. Ako je demokracija moguća bez zajedničkog nacionalnog identiteta, onda ustavni patriotizam pruža bolje prilike realizacije ciljeva političke jednakosti i to zbog otvorenog procesa dijaloga o odgovarajućem sadržaju ustava. Dok se pod nacionalizmom manjine bore da bi ih se čulo na bazi jednakosti, ustavni se patriotizam temelji na ideji da je politička jednakost od središnje važnosti za demokratsku legitimnost, i to do te mjere da se čak i fundacionalni ustav zajednice stalno podvrgava javnoj reinterpretaciji. $\mathrm{U}$ tom smislu takav ustav reflektira političku jednakost svakog pojedinca unutar zajednice, bez obzira na to bili oni pripadnici većine ili manjinskih grupa. A to je jednostavno rezultat uvjerenja da svaki pojedinac u otvorenoj raspravi ima jednaki glas u oblikovanju takvog ustava.

Drugi razlog zbog kojega se ustavni patriotizam može prije braniti nego li nacionalizam odnosi se na problematični odnos što ga nacionalizam ima prema pravima pojedinca. Ako se liberalna demokracija prihvaća kao poželjni politički koncept, onda se nacionalizam svojim naglašavanjem grupnih prava suprotstavlja liberalnim nastojanjima glede individualnih prava. Povijesna pojava Ustavnog patriotizma pokazuje da je on zapravo osmišljen kako bi se nadišli problemi koje je nacionalizam stvorio na putu ostvarivanja u potpunosti liberalnih društava. Bez obzira na to radi li se o zapadnoeuropskim zemljama ili o SAD-u, ili daleko homogenijim državama poput Japana ili zemalja Istočne Europe, ustavni patriotizam naglašava jednaka prava svakog pojedinca na slobodu izražavanja i kontinuirano reinterpretiranje način prema kojemu konstiturana 'grupa' izražava univerzalne principe u svom ustavu. U tom smislu, ustavni je patriotizam konzistentan $\mathrm{s}$ opredjeljenjem za individualna prava i priznavanje da su ona samo središte liberalne demokracije.

Naposljetku, ustavni patriotizam nadilazi pretpostavku o inherentnoj vezi između nacionalizma i demokracije jer nudi koherentna sredstva ostvarivanja demokratske prakse na transdržavnoj razini, ali i načine izgradnje demokratskih institucija koji se mogu lakše braniti nego što ih nudi mogućnost ,supranacionalnog nation-buildinga“. Upravo su zbog toga mnogi naglašavali relevanciju ustavnog patriotizma za EU-integracijski projekt gdje se zajednički ustav kao postojeći funkcionalni ustav (bez obzira na njegovu formu) pojavljuje prije svega kao pitanje 
odgovarajućeg ustavnog identiteta i ustavnog subjekta. A iz njega i EU-ustavni patriotizam koji bi trebao biti ,specifičan radi principa, poput tolerancije, i praksi, poput civilizirane konfrontacije..." ${ }^{\text {"86 }}$

\section{PRIMIJENJENI USTAVNI PATRIOTIZAM: PRIMJERI EU, KANADE}

Poput nacionalizma, tako je i ustavni patriotizam način privrženosti koja se temelji na „posebnoj konstelaciji izlaza, glasa i lojalnosti“. Tu je konstelaciju istraživao $\boldsymbol{J}$. E. Fossum u komparativnoj studiji o ustavnom patriotizmu na primjeru EU i Kanade. Uspostavljanje razlike između ,prvog“ i ,drugog“ ustavnog patriotizma ukazuje na potragu u kojoj se doktrini nacionalizma traži jednako vrijedna alternativa. ${ }^{87}$

Kanada je jedna od rijetkih zemalja koja je omogućila demokratske uvjete za teritorijalni izlazak subdržavnih jedinica. Formiranje EU može se promatrati i kao

86 „Europe has now such a constitution... It works. Why fix it“", usp. J. H. H. Weiler, FEDERALISM AND CONSTITUTIONALISM: EUROPE'S SONDERWEG, p. 14; http:// jean monnetprogram. org/archive/ papers/00/001001.htmlp. 14; S. Weichlein, COSMPOLITANISM, PATRIOTISM, NATIONALISM, http://doc.rero.ch/record/200211/files/Weichlein_Cosmopolitanism_patriotism nationalism_m.pdf; J. W. Muller, Seven Ways to Misunderstand Constitutional Patriotism, Politeia, XXV, 96, 2009., pp. 20-24; S. Vrabec, Konstitucionalizam, europski ustav i europski identitet u Habermasovim političkim spisima, Politička misao, god. 51, br. 4, 2014., str. 7-25; Jan-Werner Müller, CONSTITUTIONAL PATRIOTISM BEYOND THE NATION-STATE: HUMAN RIGHTS, CONSTITUTIONAL NECESSITY,AND THE LIMITS OF PLURALISM, Cardozo Law Review, Vol. 33, 2012., p. 1933.

\begin{tabular}{|l|l|l|}
\hline & USTAVNI PATRIOTIZAM I. (UP I.) & USTAVNI PATRIOTIZAM II. (UP. II) \\
\hline IZLAZ & $\begin{array}{l}\text { - Umjerena 'kozmopolitanska otvorenost' } \\
\text { prema osobama i argumentima } \\
\text { - Odredbe o izlasku odnose se samo na } \\
\text { komunikacijsku zajednicu a ne primjenjuje } \\
\text { se na teritorijalne entitete }\end{array}$ & $\begin{array}{l}\text { - Visoko 'kozmopolitanska otvorenost' } \\
\text { prema osobama i argumentima } \\
\text { - Odredbe o izlasku sub-jedinica iz } \\
\text { zajednice u suglasnosti s demokratskim } \\
\text { normama }\end{array}$ \\
\hline GLAS & $\begin{array}{l}\text { - Prava koja osiguravaju individualnu } \\
\text { autonomiju } \\
\text { - Komunikacija cilja jačanje sporazuma } \\
\text { o zajedničkim normama: pragmatičnim, } \\
\text { etičnim i moralnim } \\
\text { - Komunikacija jača solidarnost i osjećaj } \\
\text { zajedništva }\end{array}$ & $\begin{array}{l}\text { - Prava koja osiguravaju osobnu } \\
\text { autonomiju } \\
\text { - Komunikacija cilja pronalazak djelatnih } \\
\text { sporazuma } \\
\text { - Komunikacija jača povjerenje u } \\
\text { procedure i prava } \\
\text { - 'Negativni glas' }\end{array}$ \\
\hline LOJALNOST & $\begin{array}{l}\text { Pozitivan stav prema ustavnim normama o } \\
\text { kulturi } \\
\text { Pozitivna identifikacija sa zajednicom }\end{array}$ & $\begin{array}{l}\text { - Ambivalentni stav prema bilom kojem } \\
\text { obliku pozitivne vjernosti } \\
\text { - Sistemsko odobravanje kroz kritiku }\end{array}$ \\
\hline
\end{tabular}

87 J. E. Fossum, Constitutional patriotism: Canada and the European Union, RECON Online Working Paper 2007/04, www.reconproject.eu/projectweb/portalproject/RECONonline WorkingPapers. html 
eksplicitni odgovor na etnički nacionalizam i kao slučaj mogućeg izlaza iz europske prošlosti nacionalizma. EU također omogućuje teritorijalni izlazak (Greenland 1984.). Takvu odredbu sadrži i EU ustavni ugovor. I Kanada i EU su multietničke i multinacionalne. I jedna i druga formacija testirala je ili prekoračivala granice nacionalne vjernosti. U tom su smislu ovdje postojali brojni pokušaji oblikovanja vjernosti koja evocira ustavni patriotizam.

Poseban značaj konstelaciji „glasa, lojalnosti i izlaska“ u EU i Kanadi daju tri relevantne dimenzije koje su od centralnog značaja za ustavni patriotizam. (i) Prije svega su to povelje o slobodama koje su od središnjeg značaja u ucjepljivanju smisla vjernosti bliskog ustavnom patriotizmu i nastojanje izgradnje institucionalnih uvjeta za njihovo ostvarivanje. Individualna prava su prema tome centralni preduvjet za afirmaciju ,glasa“. (ii) Druga se dimenzija odnosi na dijelove doktrina središnje politike o zaštiti i promocije različitosti. Ovdje se prije svega ukazuje na mjere multikulturalizma kao njezina eksplicitnog priznavanja. Ovdje posebno strši pitanje okvira mjera kojima je smisao implicitno ili eksplicitno produbljivanje smisla lojalnosti u odnosu na različite načine života. (iii) Identifikacija mogućih odredaba o teritorijalnom izlasku smatra se ustvari testom državnosti, ili suprotno, indikatorima stupnja razine kozmopolitizma svakog posebnog entiteta.

Iskustvo EU i Kanade pokazuje da su na djelu dvije interpretacije ustavnog patriotizma od kojih se svaka temelji na posebnoj konstelaciji ,izlaska, glasa i lojalnosti“. Nema identičnih odgovora u diskusiji o bitnim pitanjima identiteta i pripadanja. Pitanje koje ostaje otvoreno u oba slučaja jest u kojoj se mjeri mogu osigurati uvjeti da se takva diskusija odvija na miroljubiv i međusobno respektabilan način. ${ }^{88}$

\section{USTAV REPUBLIKE HRVATSKE IZMEĐU USTAVNOG NACIONALIZMA I USTAVNOG PATRIOTIZMA}

Većina europskih postsocijalističkih ustava usvojenih neposredno nakon sloma socijalizma 1989./1990. imala je za posljedicu restauraciju „države-nacije klasičnog westphalijskog tipa“. A u takvoj državi ustavi su se uglavnom razumjeli kao ,institucionalne konstelacije, kao refleks temeljnih prava, kao izraz nacionalnog jedinstva i identiteta... i kao replika modernih, poznatih formi konstitucionalizma“" ${ }^{89}$ U većini je tih država, od Poljske preko postjugoslavenskih zemalja do Bugarske, oživjela tradicija nacionalizma koja je eksplicite favorizirala homogeni, kulturni

88 J. E. Fossum, op. cit. 16.

89 P. Blokker, Constitutionalism and Constitutional Anomie in the New Europe (November 1, 2010). Available at SSRN: http://ssrn.com/abstract=1719095 or http://dx.doi.org/10.2139/ ssrn. 1719095 
identitet većine kao temelja stabilnog ustavnog poretka, i koja je u tom cilju radi većinskog ideala podvrgavala ili asimilirala manjinske kulture. Nacionalizam je početkom 1990-ih djelovao kao „najkorisnija mobilizirajuća ideologija zato što je ona automatski garantirala većinsku podršku i legitimaciju vlasti u prvim demokratskim izborima“". ${ }^{90}$ Tu ideologiju slijedi ustavni nacionalizam jer on svoje zahtjeve za nacionalnim samoodređenjem, ideologijom i suverenitetom locira $\mathrm{u}$ formalnim ustavnim instrumentima. ${ }^{91}$

Na komparativnom planu fenomen ustavnog nacionalizma (constitutional nationalism) definira Robert M. Hayden za kojega su bivše jugoslavenske republike: Hrvatska, Srbija, Slovenija i do jedne mjere Makedonija nakon prvih slobodnih izbora 1990. godine stvorile...

„... sistem ustavnog nacionalizma, što znači ustavne i legalne strukture koje privilegiraju članove većinske (etničke) nacije nad manjinama. Takvi su ustavni i legalni sistemi služili institucionalizaciji permanentne diskriminacije protiv manjina, sasvim suprotno od onoga što Amerikanci nazivaju affirmative action. ${ }^{692}$

Ustavni nacionalizam postsocijalističkih republika manifestirao se u pokušaju pomirenja dviju suprotstavljenih ideja suvereniteta: teritorijalnog i etnonacionalnog. Kako su naposljetku ustavi političko-pravni dokumenti (,političke platforme izražene u pravnim pojmovima“), a politička suština ustavnog nacionalizma je posvemašnji suverenitet dominantne nacije, to se u takvim režimima, uprkos njihovu pozivanju na pravo samoodređenja, demokraciju i jednakost, manjinska populacija realno alijenira što za posljedicu ima umanjenje demokracije i slobode za sve te otvaranje sukoba različitog intenziteta. Hayden izvlači dva zaključka iz svog opisa stanja: jedan je politički, a drugi kulturni. Prvo, ako demokracija traži zajednicu jednakih građana, ili zajednicu u kojoj se - u najmanju ruku - zahtijeva zaštita manjina, onda je etnonacionalno samoodređenje antidemokratski princip.

90 A. Sajo (1993.), Protecting Nation States and National Minorities: A Modest Case for Nationalism in Eastern Europe, The University of Chicago Law School Roundtable: Vol. 1: Iss. 1, Article 13. Available at: http://chicagounbound.uchicago.edu/roundtable/vol1/iss 1/13

91 „Donošenjem novoga hrvatskoga Ustava učinili smo ono na što nas je obvezao hrvatski narod i velika većina građana Hrvatske na prvim slobodnim višestranačkim izborima (22. travnja i 6. svibnja) ove godine. Oni su na plebiscitarni način dali svoj glas za slobodnu, demokratsku i suverenu hrvatsku državu i zato je Ustav, koji danas svečano proglašujemo, izražaj njihove volje, potvrda nacionalnoga suvereniteta hrvatskog naroda i ozbiljenje ustavno-politčkoga mandata koji smo od naroda dobili na izborima. Novim hrvatskim Ustavom Republika Hrvatska ustavnopravno se u potpunosti svrstava u krug suverenih europskih demokratskih država, kojima je civilizacijski i povijesno uvijek pripadala." F. Tuđman, Govor u prigodi proglašenja Ustava Republike Hrvatske, Zagreb, 22. prosinca 1990., http://www.tudjman.hr/ govori/proglasenje-ustava-republike-hrvatske/

92 R. M . Hayden, Constitutional Nationalism in the Formerly Yugoslav Republics, The National Councuil for Soviet and East European Research, The University of Pittsburgh, 1993, p. 32, https://www. ucis. pitt.edu/nceeer/pre1998/1993-807-20-4-Hayden.pdf 
Drugo, na kulturnom planu pozivanje na ustavni nacionalizam u ovim europskim prostorima može odvesti prema oživljavanju one teorije i prakse koja je vojno ili birokratsko „etničko čišćenje“ držala gotovo neizbježnim. ${ }^{93}$

Ustavni nacionalizam, dakle, ne samo da uspostavlja nego pokušava i zaštititi konstrukciju nacije kao prostor , jedinstva jezika, kulture i krvi““. U toj je ideji nacija „kolektivni pojedinac“ tj. individualni akter koji ima vlastito mjesto u ljudskoj zajednici, a prema naciji fizički pojedinci nemaju prvenstvo. S druge strane, iz jednakosti građanstva isključuju se svi oni koji ne pripadaju titularnoj naciji. Prema tome, za ove je države pravo pitanje bilo koji će model države primijeniti kako bi se zadovoljili zahtjevi legitimiteta, jednakosti i zaštite manjina. Drugim riječima, može li se politička integracija i lojalnost postići bez stigmatizacije onog „Drugog“"?94 Pozitivan odgovor trebao bi omogućiti drugi tip patriotizma, moguće ustavni patriotizam ili ,ideja ustavnog domoljublja“ koja pokušava...

,... okupiti građane oko vrijednosti koje proizlaze iz ustavnih principa, sloboda i prava, što je nacionalno otvoren i nediskriminirajući okvir, koji omogućava privrženost državi na temelju građanskih vrijednosti." "95

A uporište takve mogućnosti koja ide protiv rigidnog ustavnog nacionalizma i njegovih posljedica unatoč svemu je bio i ostaje čl. 3. Ustava RH (1990.) koji govori o ustavnim vrednotama i njihovu tumačenju.

Sloboda, jednakost, nacionalna ravnopravnost i ravnopravnost spolova, mirotvorstvo, socijalna pravda, poštovanje prava čovjeka, nepovredivost vlasništva, očuvanje prirode i čovjekova okoliša, vladavina prava i demokratski višestranački sustav najviše su vrednote ustavnog poretka Republike Hrvatske i temelj za tumačenje Ustava. ${ }^{96}$

Na toj normativnoj podlozi djeluju ustavni suci kao „suštinski javni interpreti“ čija je uloga donositi odluke o značenju pravnih normi. Oni su ,javni“ ne samo zato što su državni agenti ili zato jer se angažiraju u tumačenju javnog prava, oni

93 R. M. Hayden, op. cit., p.

94 Usp. S. Lacković, CONSTITUTIONAL PATRIOTISM AS AN ALTERNATIVE TO NATIONALIST CONSTRUCTION OF POLITIY, Budapest, 2007., p. 14; P. Maldini, Nationalism in Croatian Transition to Democracy:Between Structural Conditionality and the Impact of Legacy of History and Political Culture, Suvremene teme, (2012.) god. 5., br. 1; James J. Sadikovic, FORGING CONSENSUS: HOW FRANJO TUĐMAN BECAME AN AUTHORITARIAN NATIONALIST, Review of Croatian History, Vol. VI, No.1 Travanj 2011.; Robert Skenderović, GREAT SCHOLARLY AUTHORITIES AND SMALL NATIONS - THE FORMATION OF HISTORICAL NARRATIVES ON FRANJO TUĐMAN AND THE HOMELAND WAR, Review of Croatian History, Vol. XI, No.1 Tr2015.

95 D. Romac, Domoljublje na steroidima, http://www.novilist.hr/Komentari/Kolumne / Zlu -netrebalo-Denisa-Romca/Domoljublje-na-steroidima; J. Pavičić, Patriotizam s čekićem u ruci, http:// www. jutarnji.hr/komentar-jurice-pavicica-patriotizam-s-cekicem-u-ruci/1124157/

96 Ustav RH, čl. 3., http://www.sabor.hr/Default.aspx?art=1840 
su javni zbog toga jer prema javnosti imaju posebnu odgovornost u eksplikaciji značenja ustavnopravnih normi. ${ }^{97}$

7.1. Možemo li svjedočiti o hrvatskom ustavnom patriotizmu? Od nadahnutog govora prvog hrvatskog predsjednika Republike prilikom usvajanja prvog demokratskog Ustava RH iz 1990. pa do danas prošlo je već više od četvrt stoljeća. ${ }^{98}$ Kazali bi da protek vremena nije ničim umanjio dubinu emocija govornika i opravdanost razloga kojima se popratilo donošenje Ustava. No trajnost na isti način vrijedi i za neka druga pitanja u vezi s usvajanjem i ostvarivanjem prvog Ustava u Republici Hrvatskoj skrojenog prema ,standardima..., vrijednostima i institucijama američke i europske demokracije... poštivanju prava čovjeka, diobi vlasti, vladavini prava i demokratskom višestranačkom sustavu“" 99

Jedno od takvih pitanja jest i ono o integrativnoj funkciji ustava. Nekadašnji je predsjednik Ustavnog suda SR Njemačke Dieter Grimm govorio da je pitanje integrativne funkcije ustava ustvari pitanje o ,extra-legalnim učincima legalnog objekta“. ${ }^{100}$ Dok su juridičke funkcije ustava relativno jednostavne, njegove su sposobnosti da osiguraju socijalnu integraciju dosta složenije. Činjenica da je ustav pravno na snazi još uvijek ne govori o njegovoj integrativnoj snazi. Jer, ,integracija se odvija u stvarnom svijetu... Riječ je o društvenom procesu koji ustav može promovirati ali koji ustav ne kontrolira“. Grimm ustvari sugerira da integrativna funkcija ustava ovisi o onome što on naziva njegovom ,simboličkom snagom“ koja je i sama određena nizom čimbenika, prije svega njegovim povijesnim izvorima te refleksom temeljnih vrednota konkretnog društva.

Nakon stjecanja državne samostalnosti i njezina očuvanja u ratnim godinama, Republika Hrvatska je bila u poziciji da temeljem svog Ustava, unatoč njegovim ograničenostima, djeluje kao ,inkubator ustavne demokracije“ i stvara „pravom

97 Alex Schwartz, Patriotism or Integrity?: Constitutional Community in Divided Societies, Queen's University Belfast School of Law: Research Paper 2013 - 26, Oxford J Legal Studies (2011.) 31 (3): 503 526.

98 „U političkom životu svakoga naroda donošenje novoga ustava tj. temeljnoga zakona društvenopravnog poretka znači uvijek događaj iznimnoga, a ponekad i povijesnog značenja. Takve primjere nalazimo navlastito u slučajevima stjecanja nacionalne suverenosti i državne neovisnosti, ili korjenitih (revolucionarnih) društveno-političkih promjena. Ne može biti nikakve dvojbe da donošenje Ustava RH ima značajke iznimnoga povijesnoga čina. I to iz dva razloga. Prvo stoga, što ovaj Ustav označuje konačan raskid s komunističkim, tzv. socijalističko-samoupravnim, jednostranačkim sustavom, zasnovanim na društvenom vlasništvu i plansko-dogovornoj privredi. I drugo, zbog toga što on čini temeljnicu u izgradnji pune nacionalno-državne suvernosti Hrvatske: ono tvarno i duhovno stanište, u državotvornopolitičkom smislu, na kojemu će hrvatski narod moći nadograđivati i do kraja dovršiti svoj dom slobode i neovisnosti, na području unutarnjih i međunarodnih odnošaja." M. Tuđman, Govor u prigodi proglašenja Ustava Republike Hrvatske, Zagreb, 22. prosinca 1990., http://www. tudjman.hr/ govori/ proglasenjeustava-republike-hrvatske/

99 M. Tuđman, Govor u prigodi proglašenja Ustava Republike Hrvatske, Zagreb, 22. prosinca 1990. http://www. tudjman.hr/ govori/ proglasenje-ustava-republike-hrvatske/

100 D. Grimm, Integration by Constitution (2005) 3 International Journal of Constitutional Law 193208, 194. 
posredovanu solidarnost" za koju se očekivalo da će nositi sav teret integracije i legitimacije. Ipak, gotovo četvrt stoljeća nakon usvajanja svog prvog demokratskog Ustava, naša politička povijest jasno pokazuje da je hrvatsko društvo još uvijek podijeljeno društvo. U takvim društvima izazovi bavljenja prošlosti pogoršavaju se fragmentacijom i polarizacijom javne sfere. Komunikativna polarizacija nastavlja različite i uzajamno suprotne povijesne narative. A ova polarizacija posebno šteti Habermasovoj projekciji ustavnog patriotizma. J. Habermas je zamišljao da „predpolitičku“ ideju nacije može trampiti za „komunikacijsku zajednicu“ jer se upravo kroz javnu i zajedničku komunikativnu akciju pojavljuje i održava zajednička politička kultura. ${ }^{101}$

Kažu da je jedan bivši hrvatski premijer za vrijeme posjeta Izraelu govorio da se u Hrvatskoj „probija novi obrazac patriotizma“. Dnevne novine su prenijele da je u svom govoru spominjao da se...

... to novo domoljublje (...) mjeri razinom poštovanja Ustava i vladavine prava. Taj novi patriotizam uključuje sve građane, bez obzira na njihova politička i vjerska uvjerenja, i na etničko podrijetlo. Novi obrazac domoljublja isključuje svaku diskriminaciju i rasizam, a zasniva se na poštovanju ljudskog dostojanstva, na poštovanju prava manjina i iskrenoj suradnji sa susjedima. ${ }^{102}$

Ipak, podijeljene motivacije i vrijednosti koji definiraju ustavni patriotizam ,ne dolaze“, kaže A. Shwartz, „ex nihilo“. Jasno je da je ustavni patriotizam kontigentni produkt posebnih političkih događaja. Taj zaključak podupire niz primjera pa tako dijelom i hrvatska „povijesna priča“. Riječ je o povijesti u kojoj se u kontekstu konsolidirane države-nacije najprije pojavljuje integracija oko zajedničkog nacionalnog identiteta. Ono što slijedi nakon jest pitanje o tome kad se i zbog čega pojavljuje, stvara i održava onaj etos koji je iznad tog konteksta države-nacije. ${ }^{103}$ Imajući na umu hrvatsku situaciju, njezine unutarnje i vanjske odnose, vidjet će se da se fenomen ustavnog patriotizma, bilo u starom bilo u novom smislu, uvijek pojavljuje u vezi s relativno novim ustavnim situacijama i odnosima koji stalno traže akomodaciju okolnostima bilo nacionalnog bilo internacionalnog pluralizma. Kanadski je filozof Will Kymlicka govorio da će različiti ljudi ,izražavati vjernost široj zajednici jedino onda kada je sagledaju kao kontekst u kojemu će svoj identitet njegovati a ne podređivati“ “. ${ }^{104}$ Zato je i više nego prihvatljiv zaključak da u takvim

${ }^{101}$ O ulozi javnosti u generiranju postnacionalne solidarnosti v. C. Calhoun, Imagining Solidarity: Cosmopolitanism, Constitutional Patriotism, and the Public Sphere (2002.), 14 Public Culture 147-171.

${ }_{102}$ D. Knežević, Što je novi patriotizam o kojem govori Ivo Sanader?, http://www.vecernji. hr/ hrvatska/sto-je-novi-patriotizam-o-kojem-govori-ivo-sanader-845000

103 A. Schwartz, op. cit., p. 8.

${ }^{104}$ W. Kymlicka, Multicultural Citizenship, Oxford, 1995., ch 9., cit. pr. A. Schwartz, op. cit., p. 11. 
slučajevima ustavni patriotizam ne bi bio alternativa akomodaciji bilo kakvom subnacionalizmu, već prije produkt takve akomodacije. ${ }^{105}$

\section{ZAKLJUČNA NAPOMENA}

Nakon prvih američkih i francuskih ustava, veliki je broj država prihvatio pisani ustav kao temelj svog političkog sistema. Vrijedonosno pozitivan stav prema takvom ustavu najbolje je izrazio č. 16. Deklaracije o pravima čovjeka i građanina. Naime, ono društvo u kojemu nema diobe vlasti i garancija prava i sloboda nema ustav. ${ }^{106}$ Ustav je dakle sadržavao mehanizme kojima je cilj bio zaštita pojedinca protiv države. Od herojskog doba u razvoju ustavnosti započinje uspon modernog konstitucionalizma. ${ }^{107}$ Ipak, ustavi se nisu povezivali samo s izgradnjom demokracije i ograničene vlasti. Ustavi su imali i integrativnu funkciju, u smislu da su oni zajednici i onima koji su je sačinjavali trebali osigurati snalaženje s identitetom. U tom pravcu, ustavi su doprinosili procesu učvršćivanja nacije. To znači da autori Ustava RH iz 1990. nisu bili samo inspirirani demokratskim načelima ograničene vlade već su bili i patrioti odlučni da Republiku Hrvatsku emancipiraju kao novu demokratsku samostalnu i neovisnu državu.

Prema B. Ackermannu, ustav često označuje ,novi početak“ države koja treba vlastiti identitet (new beginning scenario). U takvoj državi ustav može djelovati kao snažan simbol nacionalnog identiteta. On može steći status kulturno važnog simbola. ${ }^{108}$ Štoviše, tijekom vremena on postaje izvor ustavnog patriotizma u njegovu najispravnijem smislu. A to znači ne samo u ,američkom“ smislu gdje je vjernost ustavu i njegovim načelima ,civilna religija“ već i u ,europskom“ značenju kao obranjivi oblik postnacionalnog identiteta i pripadanja. Međutim, uspjeh i brzina toga procesa ovisi prije svega o odlučnosti nastupanja ustavnih patriota protiv sve prisutnije pojave populizma kao onog oblika političkog imaginarija ustvari onog načina promatranja...

105 A. Schwartz, op. cit., p. 8.

106 Déclaration des Droits de 1'Homme et du Citoyen de 1789 (Art. 16. Toute Société dans laquelle la garantie des Droits n'est pas assurée, ni la séparation des Pouvoirs déterminée, n'a point de Constitution.) https://www. legifrance.gouv.fr/Droit-francais/Constitution/Declaration-des-Droits-de-1-Homme-et-duCitoyen-de-1789

107 B. Ackerman, Bruce, Constitutional Politics/Constitutional Law (1989.). Faculty Scholarship Series. Paper 140. http://digitalcommons.law.yale.edu/fss papers/140

108 „The New Beginning scenario deals in expressive symbols, not functional imperatives. Under this scenario, a constitution emerges as a symbolic marker of a great transition in the political life of a nation. For example, it is impossible to understand the remarkable success of the German Constitutional Court - both in jurisprudential terms and in terms of effective authority - without recognizing that the Basic Law has become, in the society at large, a central symbol of the nation's break with its Nazi past." B. Ackerman, The Rise of World Constitutionalism (1996.). Occasional Papers. Paper 4. http:// digitalcommons.law.yale.edu/ylsop papers/4 
„,... političkog svijeta koji suprostavlja potpuno ujedinjeni - suštinski fikcionalni - narod s jedne strane i manjine koje se ostavljaju izvan autentičnog (i potencijalno u potpunosti reprezentativnog) naroda s druge strane ... u populističkoj imaginaciji postoji samo narod i ilegitimni uljezi u našoj politici.“109

I naravno o jačini vjere da u ustavnoj konstelaciji Republike Hrvatske također postoji ona fiksirana zvijezda slobode od ortodoksije koja može jednako inspirirati i snažiti naše ustavne patriote kao što je snažila i hrabrila mnoge druge diljem razvijenog svijeta. ${ }^{110}$

\section{CONSTITUTIONALISATION OF PATRIOTISM}

This paper traces the long evolution of traditional ideas on patriotism and the constitution up to the appearance of the modern idea of constitutional patriotism. The idea of patriotism and its forms precisely enable insights into the process of constitutionalisation of patriotism and enlightening the process of rationalisation and differentiating patriotism which exists within the evolving culture of constitutionalism. This is done through the issues of - constitutional sentiment and their constitutionalisation, weakening and strengthening of the role of patriotism as an attachment of its own kind of the national constitution, the process of creating differences between patriotism of a classic state-nation and constitutional patriotism of modern existence and its search for structure. This paper examines the significance and place of the emergence of patriotism under the conditions of national and post national constitutional state.

\section{Key words: patriotism, constitutional patriotism, belief in the constitution, attachment to the constitution}

\footnotetext{
109 Jan-Werner Müller, CONSTITUTIONAL PATRIOTISM BEYOND THE NATION-STATE: HUMAN RIGHTS, CONSTITUTIONAL NECESSITY, AND THE LIMITS OF PLURALISM, Cardozo Law Review, Vol. 33, 5, p. 1935.

${ }^{110}$ Frazu o postojanju fiksirane zvijezde unutar ustavne konstelacije formulirao je sudac Robert Jackson u slučaju West Virginia State Board of Education v. Barnette, 319 U.S. 624 (1943.): „If there is any fixed star in our constitutional constellation, it is that no official, high or petty, can prescribe what shall be orthodox in politics, nationalism, religion, or other matters of opinion or force citizens to confess by word or act their faith therein. If there are any circumstances which permit an exception, they do not now occur to us. We think the action of the local authorities in compelling the flag salute and pledge transcends constitutional limitations on their power and invades the sphere of intellect and spirit which it is the purpose of the First Amendment to our Constitution to reserve from all official control." Sudac R. Jackson je u odluci koju je napisao za većinu (6:3) branio stajalište da je prisila na pozdrav zastavi i izjavljivanje vjernosti povreda I. i XIV. Amandmana na Ustav SAD-a te da se takvi postupci ne mogu opravdati kao sredstvo ostvarivanja patriotizma i nacionalnog jedinstva. Jackson je smatrao da je izjavljivanje vjernosti govor koji u komunikaciji nije ništa drugo nego izražavanje jednog niza ideja. Kada se takav govor pretvori u obavezu, njime se vrijeđaju vrednote I. Amandmana. Usp. http://caselaw.findlaw.com/ us-supreme-court/319/ 624. Html \#sthash. G 611AZrM.dpuf
} 